First publ. in: FEMS Microbiology Reviews 22 (1999), 5, pp. 399-419

\title{
Microbial desulfonation
}

\author{
Alasdair M. Cook ${ }^{\mathrm{a}, *}$, Heike Laue ${ }^{\mathrm{a}}$, Frank Junker ${ }^{\mathrm{b}}$ \\ ${ }^{a}$ Fakultät für Biologie der Universität, D-78457 Konstanz, Germany \\ b Estación Experimental del Zaidin, Consejo Superior de Investigaciones Cientificas, E-18008 Granada, Spain
}

\begin{abstract}
Organosulfonates are widespread compounds, be they natural products of low or high molecular weight, or xenobiotics. Many commonly found compounds are subject to desulfonation, even if it is not certain whether all the corresponding enzymes are widely expressed in nature. Sulfonates require transport systems to cross the cell membrane, but few physiological data and no biochemical data on this topic are available, though the sequences of some of the appropriate genes are known. Desulfonative enzymes in aerobic bacteria are generally regulated by induction, if the sulfonate is serving as a carbon and energy source, or by a global network for sulfur scavenging (sulfate starvation induced (SSI) stimulon) if the sulfonate is serving as a source of sulfur. It is unclear whether an SSI regulation is found in anaerobes. The anaerobic bacteria examined can express the degradative enzymes constitutively, if the sulfonate is being utilized as a carbon source, but enzyme induction has also been observed. At least three general mechanisms of desulfonation are recognisable or postulated in the aerobic catabolism of sulfonates: (1) activate the carbon neighboring the $\mathrm{C} \mathrm{SO}_{3}$ bond and release of sulfite assisted by a thiamine pyrophosphate cofactor; (2) destabilize the $\mathrm{C} \mathrm{SO}_{3}$ bond by addition of an oxygen atom to the same carbon, usually directly by oxygenation, and loss of the good leaving group, sulfite; (3) an unidentified, formally reductive reaction. Under SSIS control, different variants of mechanism (2) can be seen. Catabolism of sulfonates by anaerobes was discovered recently, and the degradation of taurine involves mechanism (1). When anaerobes assimilate sulfonate sulfur, there is one common, unknown mechanism to desulfonate the inert aromatic compounds and another to desulfonate inert aliphatic compounds; taurine seems to be desulfonated by mechanism (1).
\end{abstract}

Keywords: Fermentation; Oxidation; Reduction; Oxygenation; Hydrolysis; Sulfonate; Novel fermentation

\section{Contents}

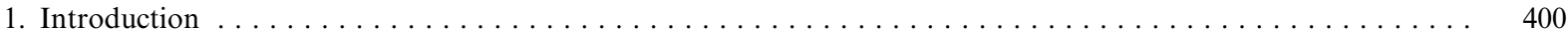

2. Organosulfonates occurring naturally, their stability and their biosynthesis $\ldots \ldots \ldots \ldots \ldots \ldots \ldots \ldots \ldots$

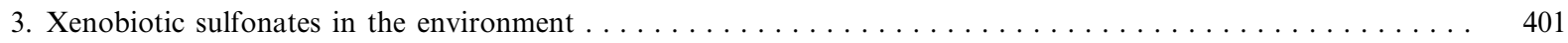

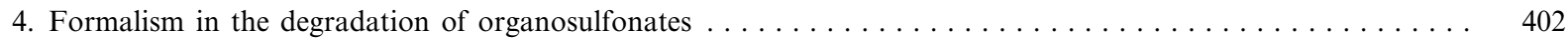

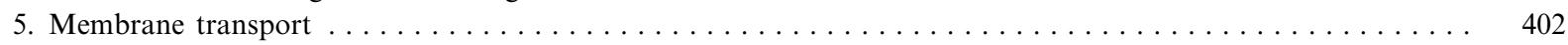

6. Aerobes dissimilating sulfonates as sources of carbon and energy $\ldots \ldots \ldots \ldots \ldots \ldots \ldots \ldots \ldots \ldots \ldots$

* Corresponding author. Tel.: +49 (7531) 884247; Fax: +49 (7531) 882966; E mail: alasdair.cook@uni konstanz.de 
6.1. Hydrolytic desulfonation of aliphatic compounds $\ldots \ldots \ldots \ldots \ldots$

6.2. Monooxygenases and desulfonation of aliphatic compounds $\ldots \ldots \ldots \ldots 4$

6.3. Dioxygenases and desulfonation, including hydrolytic and putative reductive reactions . . . . . . . . 404

6.3.1. Setting the scene for desulfonation of the aromatic ring, largely with naphthalenesulfonates . . . . 404

6.3.2. The benzenesulfonate/ $p$ toluenesulfonate dioxygenase system $\ldots \ldots \ldots \ldots 4$

6.3.3. The degradation of $p$ toluenesulfonate via the $p$ sulfobenzoate dioxygenase system $\ldots \ldots \ldots 4$

6.3.4. The putative degradation of $p$ toluenesulfonate via a reductive reaction $\ldots \ldots \ldots 406$

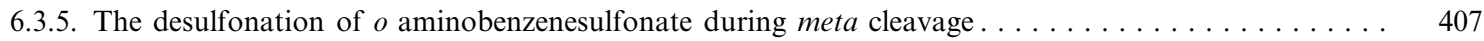

6.3.6. The hydrolytic desulfonation of $p$ aminobenzenesulfonate after ring cleavage $\ldots \ldots \ldots 408$

7. Fungal peroxidases and arenesulfonates $\ldots \ldots \ldots \ldots \ldots$

8. Aerobes assimilating sulfonate sulfur $\ldots \ldots \ldots \ldots \ldots$

9. Anaerobes dissimilating sulfonates as sources of carbon and energy $\ldots \ldots \ldots 410$

9.1. Sulfonates as electron acceptors in anaerobic respiration $\ldots \ldots \ldots \ldots 410$

9.2. Sulfonates as electron donors in anaerobic respiration $\ldots \ldots \ldots \ldots \ldots 11$

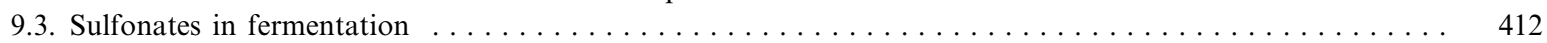

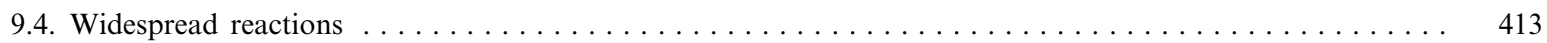

10. Anaerobes assimilating sulfonate sulfur $\ldots \ldots \ldots \ldots 13$

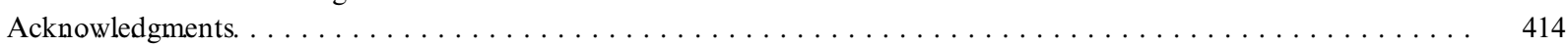

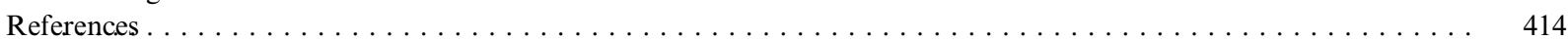

\section{Introduction}

Sulfonated organic compounds, here those with a $\mathrm{C} \mathrm{SO}_{3}$ moiety, influence our picture of the world around us, whether the words are used figuratively or literally. The natural product taurine (Fig. 1) has roles in vision, neural function and the digestive tract, amongst others [1]. Many dyestuffs (Fig. 2), which add color to e.g. inks, clothes or foodstuffs, are sulfonated. As there is now little voluble complaint about sulfonated compounds in the environment, especially after the development of sensitive analytical methods (e.g. [2 4]), it seems likely that extensive degradation occurs, despite the poor biodegradability of at least some sulfonates (e.g. [3,5 8]). This review explores these degradative phenomena, which, over the years, writers with very different backgrounds have approached (e.g. [9 18]). Recent advances, however, allow a newly rationalized overview of the field.

\section{Organosulfonates occurring naturally, their stability and their biosynthesis}

Strictly, organosulfonates are those compounds containing the $\mathrm{SO}_{3}$ moiety, so sulfate esters are O sulfonates, which have a very wide occurrence naturally [19]. The O sulfonates are usually [19], but not always [20], cleaved hydrolytically by enzymes in EC 3.1.6.- (sulfuric acid hydrolases). $\mathrm{N}$ Sulfonates are also known (e.g. $\mathrm{N}$ sulfoglucosamine, representing heparin) and appear to be subject to facile hydrolysis by enzymes in EC 3.10.1.(acting on sulfur nitrogen bonds). The $\mathrm{C}$ sulfonates are thermodynamically much more stable [21] and are not subject to chemical hydrolysis (taken as general knowledge by e.g. [22]). One can thus anticipate a different biochemistry in the degradation of these $\mathrm{C}$ sulfonates, compared with the $\mathrm{N}$ and $\mathrm{O}$ sulfonates. The sulfur atom in $\mathrm{C}$ sulfonates would appear to be in the $5+$ oxidation state ([23,24]; cf. [18]).

Until recently, the naturally occurring sulfonates were considered to be relatively few in number, though often in important functions (e.g. taurine, coenzyme $\mathrm{M}$, the plant sulfolipid, sulfolactate and methanesulfonate in Fig. 1). It is now clear that organic matter in soils (e.g. [25]) and in marine sediments [26] is sulfonated, and determinations of fractions from river samples by pyrolysis-mass spectrometry indicate this to be humic material [27]. As humus is subject to biophysical and biochemical alteration [28], including a relatively rapid flux through the sulfonate pool [29,30], one can fairly presume that the number of sulfonated compounds occurring naturally is very high. Indeed, biotransfor- 
<smiles>[NH3+]CCS(=O)(=O)[O-]</smiles>

taurine<smiles>O=S(=O)(O)CCS</smiles>

coenzyme M<smiles>N[C@@H](CS(=O)(=O)[O-])C(=O)[O-]</smiles>

cysteate<smiles>CS(=O)(=O)O</smiles>

methanesulfonate<smiles>O=S(=O)(O)CCO</smiles>

isethionate<smiles>O=C(O)CS(=O)(=O)[O-]</smiles>

sulfoacetate<smiles>O=C([O-])C(O)CS(=O)(=O)[O-]</smiles>

sulfolactate

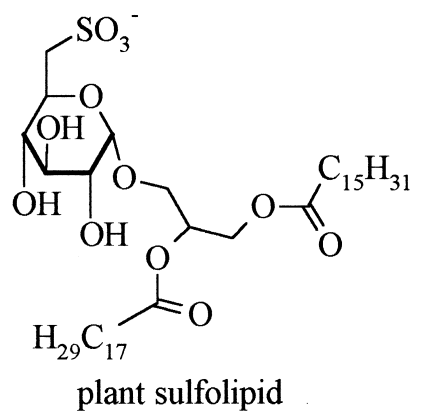<smiles></smiles>

aeruginosin $\mathrm{B}$

\section{humic material}

Fig. 1. Some naturally occurring organosulfonates. Taurine, discovered in 1836, indicates how long biologists have worked with sulfonates [1]. The sulfonate of methanogens, coenzyme M, is a much more recent discovery (cf. [161]), while the importance of methanesulfonate in the sulfur cycle has only now been recognized [69]. Cysteate was first observed in biological systems as a weathering product from cysteine in wool [162], but it is now better known as an intermediate in one pathway of taurine formation [1] or as a precursor [163] of the major spore component, sulfolactate [164]. Isethionate, initially found as a major anion in squid nerve [22], is now known to have a wider distribution [165]. Sulfoacetate is a degradative intermediate [166] from sulfoquinovose in the plant sulfolipid in the thylakoid membrane [40]. Bacterial and diatomal sulfolipids (not shown) are also known [167,168]. An undefined, but presumably aliphatic compound is found in high concentrations in plasma cells from heart samples of Ascidia ceratodes [23]. In contrast to these aliphatic compounds, only one defined aromatic sulfonate seems to be known, aeruginosin B [169]. Undefined sulfonates in soils, largely in humic materials, and in marine sediments seem to be widespread [25 27]. Humic material is characterized by its heterogeneity [28], so, as it presumably represents a major reservoir of natural organosulfonate, it is presented in the figure, but it cannot be given a structure.

mation of these numerous organosulfonates occurs naturally [30], so perhaps one should not be surprised when xenobiotic compounds are desulfonated.

There would appear to be two general routes to generate $\mathrm{C}$ sulfonate bonds. One route with many variations involves oxygenation of cysteine sulfur to the sulfinate (EC 1.13.11.20), decarboxylation (EC 4.1.1.29) and a subsequent oxidation (e.g. EC 1.8.1.3) to yield taurine and a large number of its derivatives [1]. Alternatively there is addition of sulfite at a $\mathrm{C} \mathrm{C}$ double bond as in the synthesis of coenzyme $\mathrm{M}$ [31], a variant of which is probably involved in the synthesis of the sulfoquinovose moiety of the plant sulfolipid [32].

\section{Xenobiotic sulfonates in the environment}

The detergents used to clean clothes, dishes, or floors, usually contain sulfonated compounds, whether as surfactants [17], hydrotropic agents ( $p$-toluenesulfonate, Fig. 2) or optical brighteners [8]. Some sulfonates are used in molar excess in dyestuff processing ( $m$-nitrobenzenesulfonate, Fig. 2). Yet other sulfonates (naphthalenesulfonates, Fig. 2) enter the environment in waste streams: chemical synthesis of sulfonates typically give yields of 80 $90 \%$ with many sulfonates as by-products [33], and many of these compounds can be detected in e.g. rivers [3] or seepage from waste dumps [34,35]. In 
addition, it is clear that some sulfonates in the environment (e.g. 'alachlor-ethanesulfonate', Fig. 2) are generated biologically from non-sulfonated xenobiotic compounds [36]. Further sulfonates or derivatives, e.g. saccharine (Fig. 2) enter the environment via foodstuffs.

An interest in desulfonation reactions involving xenobiotic compounds has been apparent since about 1950 (cf. [37]), though thorough proof of a desulfonation reaction was to wait some 15 years, till arguments about the degradation of branchedchain alkylbenzenesulfonate surfactants forced direct analyses to be done (cf. [38,39]). Indeed, the nonbiodegradability of the first generation of benzenesulfonate surfactants (e.g. [10]) led at least one author to consider the plant sulfolipid as a replacement [40]. Another 25 years went past before the first enzyme desulfonating a xenobiotic compound was purified [41], but the pace of development and the level of understanding have increased markedly in the meantime.

\section{Formalism in the degradation of organosulfonates}

There appear to be no reports of the accumulation of naturally occurring sulfonates under anoxic conditions, but until recently it was believed that arenesulfonates were degraded under oxic conditions only $[12,42]$, and desulfonation reactions in anaerobes were ignored. The rapidly growing understanding of anaerobic desulfonation reactions involving aliphatic and aromatic compounds, and their abundance, is now illustrated in Sections 9 and 10.

It is helpful to consider critically the role of the organosulfonate in the metabolism of the organism under study. In aerobes, the sulfonate can be found as a carbon and energy source only, concomitant with excretion of the sulfonate moiety. As the organisms do not grow in the strict absence of sulfate in the growth medium [37,43], it is presumed that the catabolic activities (uptake of arenesulfonate, desulfonation and excretion of the sulfonate moiety) are independent of the supply of sulfate for growth, i.e. of a sulfate transport system. In addition, the regulation involved is largely induction of a catabolic pathway (Section 6). Alternatively, the sulfonate is used as a source of sulfur for growth with concom- itant excretion of the carbon moiety [44 48]; the regulation is a global system for scavenging sulfur (Section 8). In anaerobes, this strict formalism is perhaps better known and the different metabolic types are easily recognized; sulfonates as sulfur sources (Section 10), sulfonates as electron sinks in respiration, sulfonates as electron (and carbon) sources for e.g. nitrate respiration, and sulfonates as substrates in fermentions (Section 9). These processes will be examined in turn.

One process of almost (cf. Section 7) universal relevance for the metabolism of organosulfonates is the transport of the compound across the cell membrane. It has been largely ignored.

\section{Membrane transport}

Organic sulfonic acids are strong acids whose $\mathrm{p} K$ values, if uninfluenced by other substituents, are probably negative [49]. This means that the sulfonate group is charged at physiological $\mathrm{pH}$ values, with the consequence that transport is required to bring the substrate into contact with the cytoplasmic enzymes involved in its degradation (cf. Section 7 for the reverse situation).

Biedlingmaier and Schmidt detected transport systems for e.g. ethanesulfonate or taurine in Chlorella fusca [50,51] and in cyanobacteria [52] and reported on their kinetics. Thurnheer et al. [53] offered indirect evidence for transport processes in that the cell membrane of Alcaligenes sp. strain O-1 is selectively permeable to isomeric arenesulfonates. Direct transport assays were done by Locher et al. [54] with Comamonas testosteroni T-2 and p-toluenesulfonate. They presented evidence for an inducible, secondary proton symport system, which was not sufficiently stable to allow biochemical work to be done.

Genetic evidence for a transport system for taurine is available in Escherichia coli MC4100 [55]. The genes are located in an operon termed tauABCD (accession number D85613; [55]), and TauABC comprise an $\mathrm{ABC}$-type transporter of unknown substrate specificity (see also Section 8). Genes for a putative transport system for methanesulfonate (cf. [56]) are under study, and manuscripts are pending (J.C. Murrell, personal communication). 
<smiles>Cc1ccc([Se])cc1</smiles>

$p$-toluenesulfonate<smiles>O=C([O-])c1nn(-c2ccc(S(=O)(=O)[O-])cc2)c(O)c1/N=N/c1ccc(S(=O)(=O)[O-])cc1</smiles>

tartrazine<smiles>O=[N+]([O-])c1cccc([S+](=O)[O-])c1</smiles>

$m$-nitrobenzenesulfonate<smiles>O=c1[nH]n(S(=O)(=O)c2ccccc2)c2ccccc12</smiles>

saccharine<smiles>O=S(=O)([O-])c1cccc2ccccc12</smiles>

naphthalenesulfonate

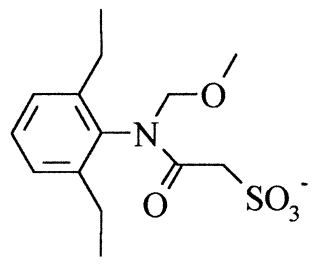

alachlor-ethanesulfonate

Fig. 2. A few xenobiotic sulfonates. Many of these compounds are very simple, and, as in the case of the naphthalenesulfonate, representative for a large number of substituted compounds. The azo dyestuff, tartrazine, represents a widely used class of dyestuffs. 'Alachlorethanesulfonate' represents a class of compounds formed from chloroacetanilide herbicides, alachlor in this case [36]. More information on xenobiotic sulfonates can be found elsewhere (e.g. [170]).

\section{Aerobes dissimilating sulfonates as sources of carbon and energy}

Whereas a wide range of compounds has been shown to serve as a sole source of carbon and energy for the growth of aerobic bacteria (e.g. [6]), be this in pure culture or in (model) sewage, there is much less information available on the reactions involved, especially on the desulfonations. One can now be sure that there are hydrolytic desulfonations, desulfonations inherent in monooxygenations and in dioxygenations, and a formally reductive desulfonation is postulated.

\subsection{Hydrolytic desulfonation of aliphatic compounds}

The first desulfonation to be characterized was that of sulfoacetaldehyde, which is hydrolyzed quantitatively to acetate and sulfite by a thiamine pyrophosphate (TPP)-coupled lyase (EC 4.4.1.12) from several bacteria (cf. Fig. 6) [57,58]. It is possible to hypothesize an enol-adduct of the TPP whose formation is aided by loss of the sulfite anion, a good leaving group; addition of water across the double bond generates the acetate and regenerates the TPP [57]. The acetate is oxidized to $\mathrm{CO}_{2}$ and water, with anaplerotic reactions allowing channelling of intermediates for biosynthesis [59].

The first known source of sulfoacetaldehyde was taurine, but different organisms use transaminations to different amino-group acceptors (e.g. EC 2.6.1.55) (cf. [60]) or oxidation (EC 1.4.99.2) [61] for the transformation. Recent work shows that the catabolism of isethionate ([62]; cf. [63]) and possibly sulfoacetate converge at sulfoacetaldehyde [64], but it is unclear how the sulfoacetate is reduced to the aldehyde. The enzymes involved in these reactions are found in a wide range of genera including Pseudomonas [60], Acinetobacter [62], Aureobacterium and Comamonas [64].

It seems possible that the catabolism of cysteate or sulfolactate could be channelled through taurine $[65,66]$, but some preliminary enzyme work with cysteate leads one to suspect the presence of a novel desulfonation [67].

The only other known hydrolytic desulfonation is that involved with 4-sulfocatechol, which will be treated with the other aromatic compounds in Section 6.3 . 


\subsection{Monooxygenases and desulfonation of aliphatic compounds}

The monooxygenation of $n$-alkane-1-sulfonates, a family of surfactants, was detected many years ago [68], but it is only recently that a monooxygenation reaction, from Methylosulfonomonas methylovora, was characterized. The substrate is the natural product methanesulfonate [69,70] and the monooxygenase system involved $[56,71,72]$ belongs to the mononuclear iron systems better known in the bacterial oxygenation of aromatic compounds [73]. These enzymes contain an electron transport chain, that collects electron pairs from NADH on a flavin, which delivers single electrons via $[2 \mathrm{Fe} 2 \mathrm{~S}]$ ferredoxin and/ or $[2 \mathrm{Fe} 2 \mathrm{~S}]$ Rieske centers to the mononuclear iron at the reactive center (cf. [74]) where the reduced iron activates the oxygen. Activated oxygen presumably attacks the carbon atom to yield the unstable hydroxy-methanesulfonate, which spontaneously loses the good leaving group sulfite to form formaldehyde, a typical intermediate in $\mathrm{C}_{1}$ metabolism [75]. The three-component system will oxygenate ethane- and propanesulfonates, but does not accept any further substitution on the alkane.

The destabilization of the otherwise inert $\mathrm{C}^{\mathrm{SO}_{3}}$ bond by the introduction of a second heteroatom to the carbon atom, which causes spontaneous loss of sulfite, is a mechanism that will be observed many times is this review. It is presumed to be the basis of the formation of oxaloacetate from sulfosuccinate in Pseudomonas sp. strain B51 [76], though the nature of the monooxygenase here is still unknown. Another monooxygenation is presumed to be involved in the degradation of naphthalene 2,6-disulfonate [77].

\subsection{Dioxygenases and desulfonation, including hydrolytic and putative reductive reactions}

\subsubsection{Setting the scene for desulfonation of the aromatic ring, largely with naphthalenesulfonates}

The bulk of research on desulfonation has been done with aromatic compounds. Initial work reviewed by Cain [9] established the idea that dioxygenases destabilized the inert $\mathrm{C}$ sulfonate bond and that the sulfonate moiety was released as sulfite $[38,78]$, thus correcting some earlier claims that sul- fate was the direct product of desulfonation. Knackmuss' group gave more experimental support for this idea with a naphthalenesulfonate model [79]. Work with amino- and hydroxynaphthalene-2-sulfonates [80] led to Sphingomonas sp. strain BN6, but despite much work (e.g. [81]), this desulfonation has also not been examined directly because of the inactivity of the oxygenase in cell-free extracts. Indirect evidence on the nature of the oxygenase comes from an unpublished DNA sequence (accession number U65001) located adjacent to the partial DNA sequence of a putative 1,2-dihydroxynaphthalene dioxygenase (the next enzyme in the degradative pathway). A comparison of the deduced protein sequence of the ferredoxin component shows high sequence similarities with the ferredoxin components of naphthalene dioxygenase and of benzene dioxygenase.

Those working with the mononuclear iron oxygenase systems are used to characterize them into classes I, II and III, and to distinguish them from the diiron systems [82 84].

\subsubsection{The benzenesulfonatelp-toluenesulfonate dioxygenase system}

$p$-Toluenesulfonate (TS) has turned out to be a more rewarding substrate as regards elucidation of desulfonation reactions, and three different pathways for its degradation have been discovered or proposed (Fig. 3). The inducible dioxygenase which causes ring desulfonation has been separated in extracts of Alcaligenes sp. strain $\mathrm{O}-1$. The reaction catalyzed is:

$$
\mathrm{NADH}+\mathrm{O}_{2}+\mathrm{TS}+\mathrm{H}^{+} \rightarrow \mathrm{NAD}^{+}+
$$

4 methylcatechol $+\mathrm{HSO}_{3}$

The enzyme is probably a three-component system that is also benzenesulfonate dioxygenase (desulfonating) [85]. This desulfonative enzyme has an incompletely explored, broad substrate range which involves deaminating $o$-aminobenzenesulfonate $[85,86]$. The general phenomenon of spontaneous reactions following oxygenation of the ring is large, and turns out to be widespread in nature $[85,86]$. In contrast to the broad substrate range of the enzyme, however, induction of the enzyme in strain O1 is very specific [85]. 

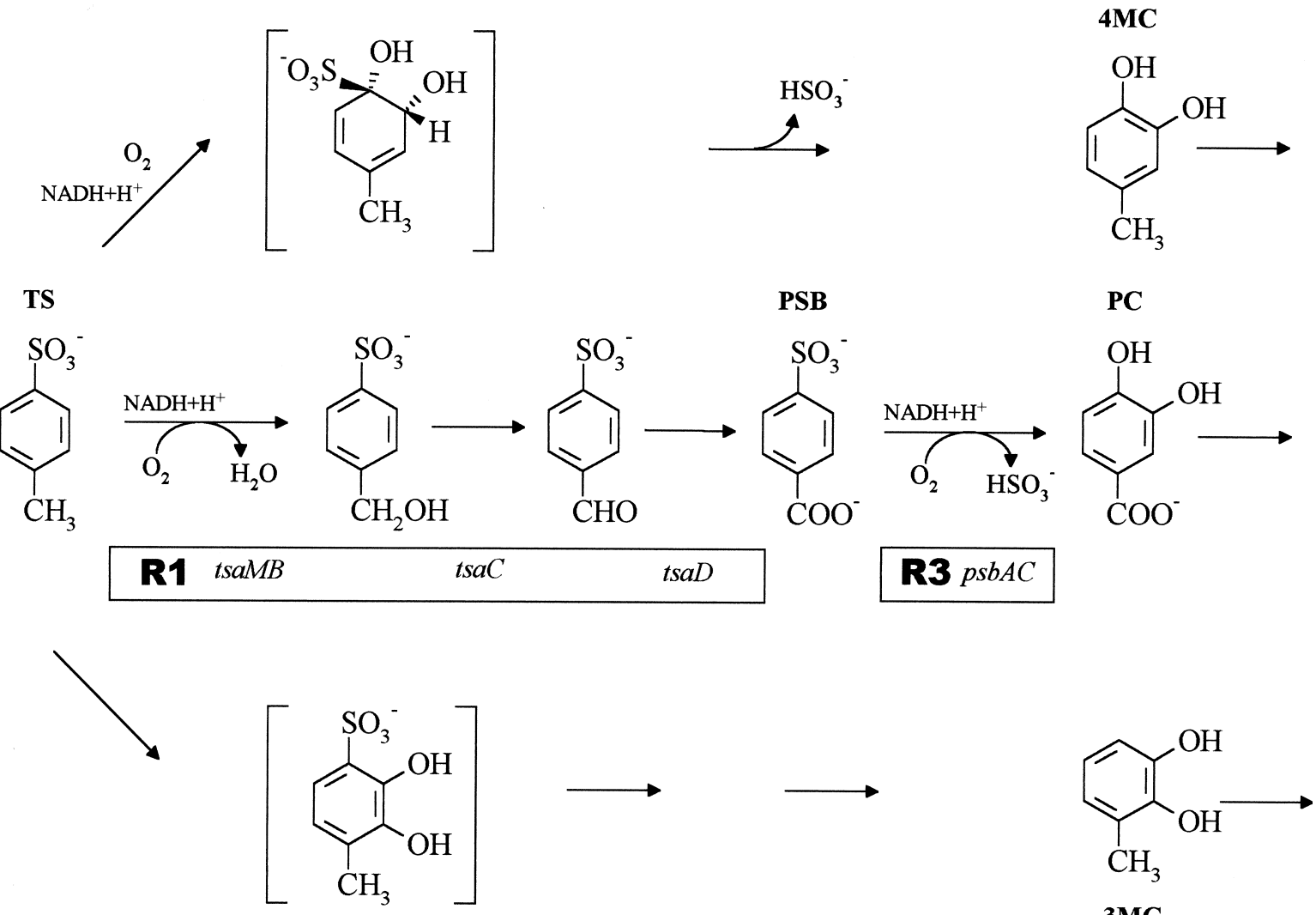

3MC

Fig. 3. Three pathways for the catabolism of $p$-toluenesulfonate. The uppermost pathway was established in Alcaligenes sp. strain O-1 [85], the middle pathway was established in C. testosteroni T-2 [41,43,90] and the tentative third pathway is derived from data with a 'pseudomonad' [38,100]. The desulfonation catalyzed by PsbAC (middle pathway) is analogous to that in the uppermost pathway (see reaction in brackets), but, to simplify the figure, it is not shown.

In bacterial nutrition, the combination of utilization of TS and benzenesulfonate is widespread [37,87 89], so it is hypothesized that an enzyme system analogous to the TS-dioxygenase system in $\mathrm{Al}$ caligenes sp. strain $\mathrm{O}-1$ is widespread. Balashov et al. $[88,89]$ find the enzyme(s) to be plasmid-encoded.

\subsubsection{The degradation of p-toluenesulfonate via the p-sulfobenzoate dioxygenase system}

The degradation of TS in Comamonas testosteroni $\mathrm{T}-2$ is currently the best understood desulfonative pathway, though there are still significant gaps in our knowledge, especially in the biochemistry and genetics of the transport system (Section 5). The initial attack (Fig. 3) is monooxygenation of the methyl side chain by a two-component monooxygenase system $[90,91]$ followed by two characterized dehydro- genases which yield $p$-sulfobenzoate (PSB). PSB is desulfonated, as predicted above, via dioxygenation by a two-component dioxygenase involving reductase C and oxygenase A (EC 1.14.12.8; a class IA system) and spontaneous loss of the leaving group, sulfite, to yield protocatechuate [41,92]:

$$
\begin{gathered}
\mathrm{NADH}+\mathrm{O}_{2}+\mathrm{PSB}+\mathrm{H}^{+} \rightarrow \mathrm{NAD}^{+}+ \\
\text {protocatechuate }+\mathrm{HSO}_{3}
\end{gathered}
$$

Reaction stoichiometry and dioxygenation have been established $[41,43]$, and the identical oxygenase component is found in two independent isolates [92].

Expression of enzyme activity allowed groups of co-regulated genes to be determined [93]. The genes 
encoding the enzymes for the degradation of TS via PSB in C. testosteroni T-2 and of PSB in C. testosteroni PSB-4 are located on two conjugative megaplasmids designated pTSA and pPSB, respectively ([94]; cf. [13]). The genes encoding degradation of protocatechuate are chromosomal in both organisms. Both plasmids were estimated at $85 \mathrm{kbp}$, but an expanded data set indicates that pTSA is about $73 \mathrm{kbp}$ [95]. pTSA belongs to the incompatibility group IncP1 $\beta$. It is readily lost under non-selective conditions, giving rise to mutant TER-1, which cannot grow with TS and was very useful for conjugation experiments to explore the catabolic genes [94].

The four genes (tsaMBCD) encoding the enzymes which convert TS to PSB comprise an operon, the tsa operon, that corresponds to regulatory unit R1 (Fig. 3) $[93,94]$, putatively with the divergently transcribed, LysR-type regulator gene, tsaR (accession number U32622) [91]. The intergenic region between tsaR and tsaMBCD shows the characteristic features of LysR-type regulated systems [96] and a putative sigma $^{70}$ housekeeping promoter for tsaMBCD is present [91]. Many newly isolated bacteria, selected to utilize TS, contain the $t s a$ operon (shown by PCR and partial DNA sequence) and show the same physiological properties as $C$. testosteroni $\mathrm{T}-2$, namely the transient excretion of the intermediates $p$-sulfobenzylalcohol and PSB during growth with TS [95]. This operon, too, seems to be widespread.

A preliminary sequence [97] is available for the putative $p s b$ operon, which corresponds to regulatory group R3 (Fig. 3) [93]. The operon structure in strain PSB-4, psbAXYCZ, is located between two copies of the 3.2-kbp insertion element IS1071 (Accession number M65135), and possibly represents a class II transposon (cf. [98]), as predicted [94]. A transposition event is observed in conjugation experiments involving strain PSB-4 (donor) and a plasmid-free, $p s b$ recipient. The $p s b$ genes transpose to the chromosome with concomitant loss of plasmid pPSB [94]. Currently, the composition of operon $\mathrm{R} 3$ is speculative, with only $p s b A$ (the oxygenase component) firmly attributed and $p s b C$ (the reductase component) tentatively ascribed; the functions of the gene products of $p s b X Y Z$, open reading frames, are still unknown.

The degradation of PSB in C. testosteroni T-2 was difficult to study for several years, because functional reductase $\mathrm{C}$ was no longer found, and its activity was complemented by reductase $\mathrm{B}$ of the toluenesulfonate methyl-monooxygenase (TsaB in Fig. 3). It was proposed that a mutation in the putative $p s b$ operon had occurred [92,94]. A culture of strain T-2 has since been recovered that was stored prior to the putative mutational event, and it apparently also encodes the $p s b A X Y C Z$ structure found in strain PSB-4, whereas $p s b X Y C Z$ seem to be missing from C. testosteroni T-2 (DSM 6577) [97], thus confirming the hypothesis on a mutation. PSB degradation is ready and widespread $[37,88,99]$, so one wonders whether the conjugative plasmids and the transposition observed represent the transmission of one operon, or whether other degradative pathways remain to be found. The nature and the location of the transport system, which differs from that for TS [54], is another open question.

\subsubsection{The putative degradation of p-toluenesulfonate via a reductive reaction}

The third pathway for the degradation of TS (Fig. 3 ) is generated from the initial identification of

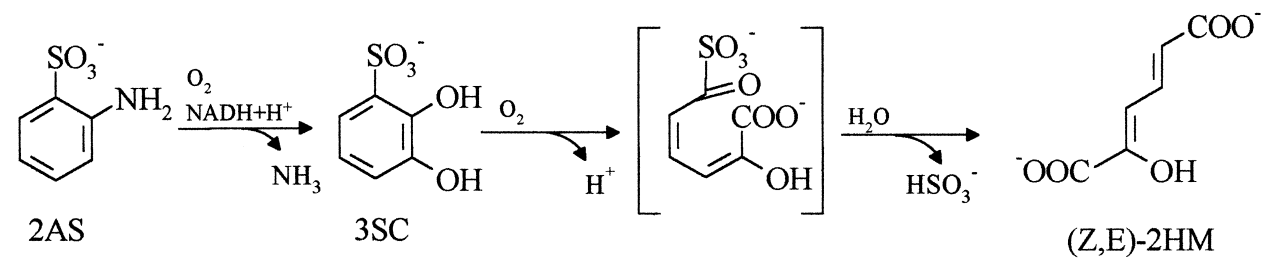

Fig. 4. The degradative pathway of orthanilate (2AS) in Alcaligenes sp. strain O-1. The oxygenation of orthanilate to generate 3-sulfocatechol (3SC) involves an intermediate analogous to that in the upper line of Fig. 3; for simplicity, it is not shown. The product from oxygenation (and subsequent spontaneous hydrolysis) of 3-sulfocatechol is shown as the relaxed form $(Z, E)$ of 2 -hydroxymuconate (2HM). In fact all isomers can be found, but the most common (99\%) is shown. This stresses the importance of spontaneous reactions in the biochemistry of degradation of aromatic compounds in general, whereas the emphasis here is on the desulfonation reaction [85,86]. 
3-methylcatechol [100] and the subsequent identification of sulfite as the primary fate of the sulfonate moiety [38]. Thus formulated, the pathway represents a desulfonation that is formally reductive, even if nothing about its nature is known. The validity of the hypothesis depends on the quality of the paper chromatographic methodology used to identify the organic intermediate. The hypothesis would be stronger, if another isolation of the organism were achieved.

\subsubsection{The desulfonation of o-aminobenzenesulfonate during meta cleavage}

The widespread ring dioxygenation with the accompanying spontaneous desulfonation and the reductive desulfonation both occur prior to ring cleavage. The degradative pathway for $o$-aminobenzenesulfonate (orthanilate) in Alcaligenes sp. strain O-1 turns out to involve a multi-component dioxygenase system which causes stoichiometric deamination to 3-sulfocatechol [85,86,101] (Fig. 4). The latter is a novel substrate for ring cleavage, and the spontaneous desulfonation is a consequence of the meta ring cleavage enzyme, which is co-induced with the ring-activating dioxygenase system.

The pathway thus contains a dioxygenation by a putative class IB enzyme in EC 1.14.12.-, and the reaction of this multi-component enzyme leads to the spontaneous loss of ammonia (Fig. 4); if the enzyme is supplied with TS, rapid dioxygenation and desulfonation occur $[53,85]$. The desulfonation of 3-sulfocatechol is caused by formation of the sulfo-aldehyde (Fig. 4), which is spontaneously hydrolyzed, probably distant from the enzyme active site [85]. So this desulfonation is brought about by an enzyme in EC 1.13.11.-, and it can equally well catalyze a standard meta cleavage of catechol [85]. As with the TS dioxygenase (desulfonating) in this organism (Section 6.3.2 and Fig. 3), the broad specificity of the enzymes is coupled to a very tight regulation of enzyme induction [85].

The degradation of orthanilate is encoded on a conjugative, IncP9 mega-plasmid, pSAH (172 kbp) in Alcaligenes sp. strain O-1 [102,103]. Intra- and interspecies matings to a plasmid-cured strain of $\mathrm{Al}$ caligenes sp. O-1 and to Pseudomonas putida PaW130, respectively, are possible. The transconjugant of strain PaW130 acquires the ability to grow

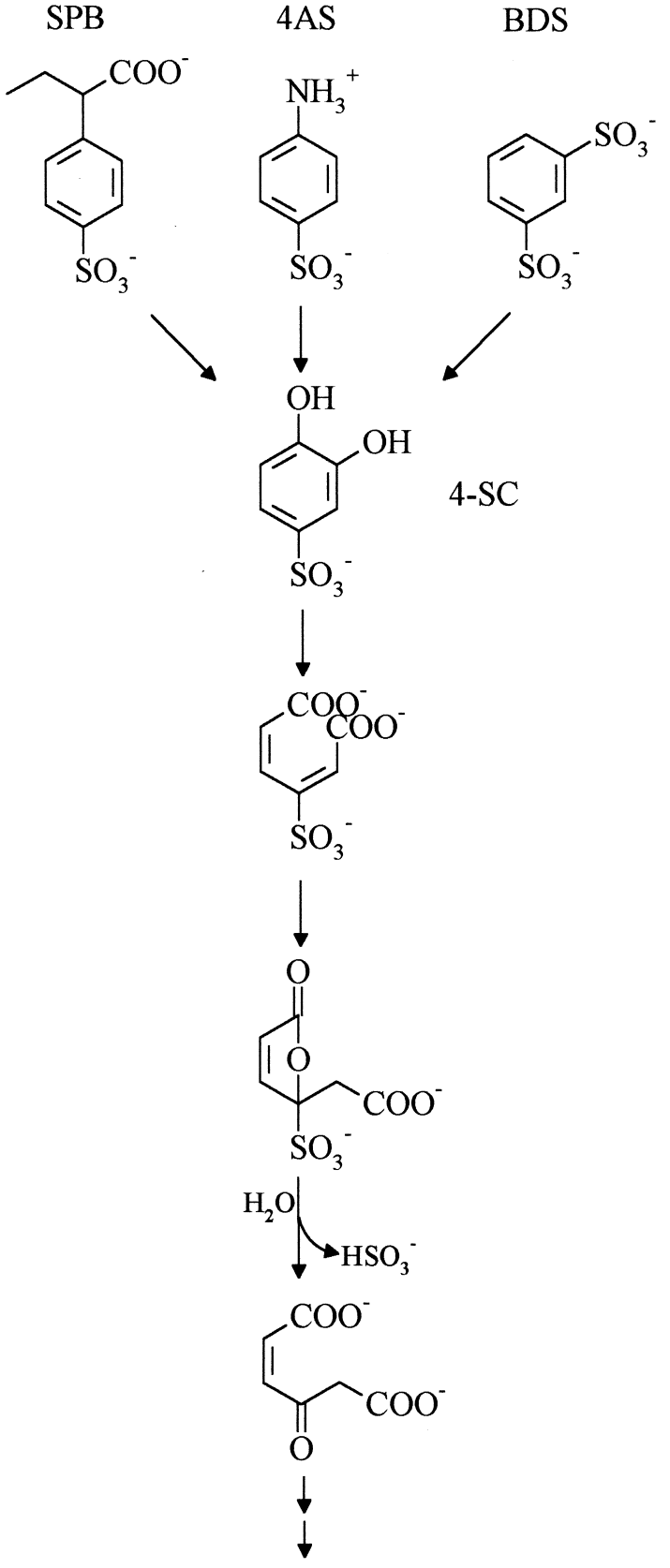

Fig. 5. Convergence of catabolic pathways for arenesulfonates at 4-sulfocatechol (4SC) and the ortho cleavage pathway established for that compound. None of the reactions leading to 4-sulfocatechol (from 2-(4-sulfophenyl)butyrate (SPB), sulfanilate (4AS) and benzene-1,3-disulfonate (BDS)) has been characterized [106 108], but the pathway in Hydrogenophaga palleronii S1 and Agrobacterium radiobacter $\mathrm{S} 2$ has been thoroughly elucidated [106]. 
with orthanilate, indicating that all the required, pSAH-encoded genes were expressed.

\subsubsection{The hydrolytic desulfonation of p-aminobenzenesulfonate after ring cleavage}

The degradative pathway for $p$-aminobenzenesulfonate illustrates yet another novel substrate for ring cleavage, 4-sulfocatechol, that is subject to ortho cleavage during which the sulfonate is retained [104] (Fig. 5). Formation of the lactone generates a relatively stable compound which includes a carbon atom carrying both an oxygen and a sulfono substituent; the previously stable $\mathrm{C}$ sulfonate bond is now subject to hydrolysis to sulfite and maleylacetate. The pathway originally found in Hydrogenophaga palleronii $\mathrm{S} 1$ and Agrobacterium radiobacter $\mathrm{S} 2$ $[105,106]$, has also been found in a mixed culture which degrades benzene-1,3-disulfonate [107] and seems to be involved in the degradation of 2-(4-sulfophenyl)butyrate [108]. This novel substrate for ring cleavage thus fulfils the role one would predict for it; acting as a focal point for converging degradative pathways. It will be interesting to see whether all intermediates of LAS degradation, and not just this sulfophenylbutyrate, follow this pathway (Fig. 5), which has not been postulated in any review (cited in [17]). Other sulfonates could also be channelled through 4-sulfocatechol, e.g. p-chlorosulfobenzoate [109], whereas $m$-amino- and $m$-nitrobenzenesulfonates $[110,111]$ could theoretically be channelled through 3- or 4-sulfocatechol. The unidentified organism, strain S1, which Locher et al. [111] isolated to utilize sulfanilate obviously also used the pathway in Fig. 5, because 4-sulfocatechol was excreted transiently.

\section{Fungal peroxidases and arenesulfonates}

Desulfonations of aromatic sulfonates in fungi have also been implied, because $\mathrm{CO}_{2}$ from the ring carrying the sulfonate was released [112], or observed directly [113]. These reactions have been attributed to (extracellular) peroxidases $[113,114]$, which sometimes lead to extensive destruction of the compounds involved, essentially as in the enzymic combustion of lignin [115]. In these cases, no transport of the sul- fonate is required, because the fungus has already exported the non-specific peroxidase.

\section{Aerobes assimilating sulfonate-sulfur}

The bacterial utilization (assimilation) of organosulfonates as sources of sulfur for growth differs from the utilization of the same compounds as carbon sources in the enzymology involved and in the genetic regulation of the enzymes. Whereas bacteria usually organize catabolic enzymes in inducible operons (see above), the utilization of sulfur is regulated at the global level of the stimulon [116]. The initial observation involved two dimensional gel-electrophoresis and showed that, under sulfate-starvation conditions, E. coli and many other Gram-positive and -negative bacteria each produces a set of proteins which is absent in the presence of sulfate. These proteins were termed sulfate-starvation induced (SSI) proteins [117] and some of them have been identified in $E$. coli (e.g. cysteine synthase CysK, sulfate-binding protein Ssp) [118] and in $P$. aeruginosa (e.g. a sulfate-binding protein) [119]. The genes regulated by the SSI stimulon are expressed when sulfate (and/or cysteine and perhaps another, species-specific compound) has been exhausted. The stimulon also seems to regulate the distribution of sulfur within the cell [116].

The natural products taurine, cysteate and isethionate are used as sole sources of sulfur by a range of bacteria and yeasts [120 124]. Where this has been examined at the molecular level, as yet only in $E$. coli, it turns out that the enzymology is totally different from the corresponding reaction when the carbon moiety is utilized. Taurine is no longer subject to transamination and hydrolysis (Section 6.1. and Fig. 6) but to a 2-oxoglutarate-dependent dioxygenation (EC 1.14.11.-) that presumably yields the unstable 1-hydroxy-2-aminoethanesulfonate which spontaneously loses sulfite with concomitant formation of aminoacetaldehyde. Taurine is the preferred substrate, but pentanesulfonate, hexanesulfonate, 3-(Nmorpholino)propanesulfonate (MOPS) and 1,3-dioxo-2-isoindolineethanesulfonate were also desulfonated at significant rates; the first three sulfonates also serve as sulfur sources for E. coli [55,125]. 


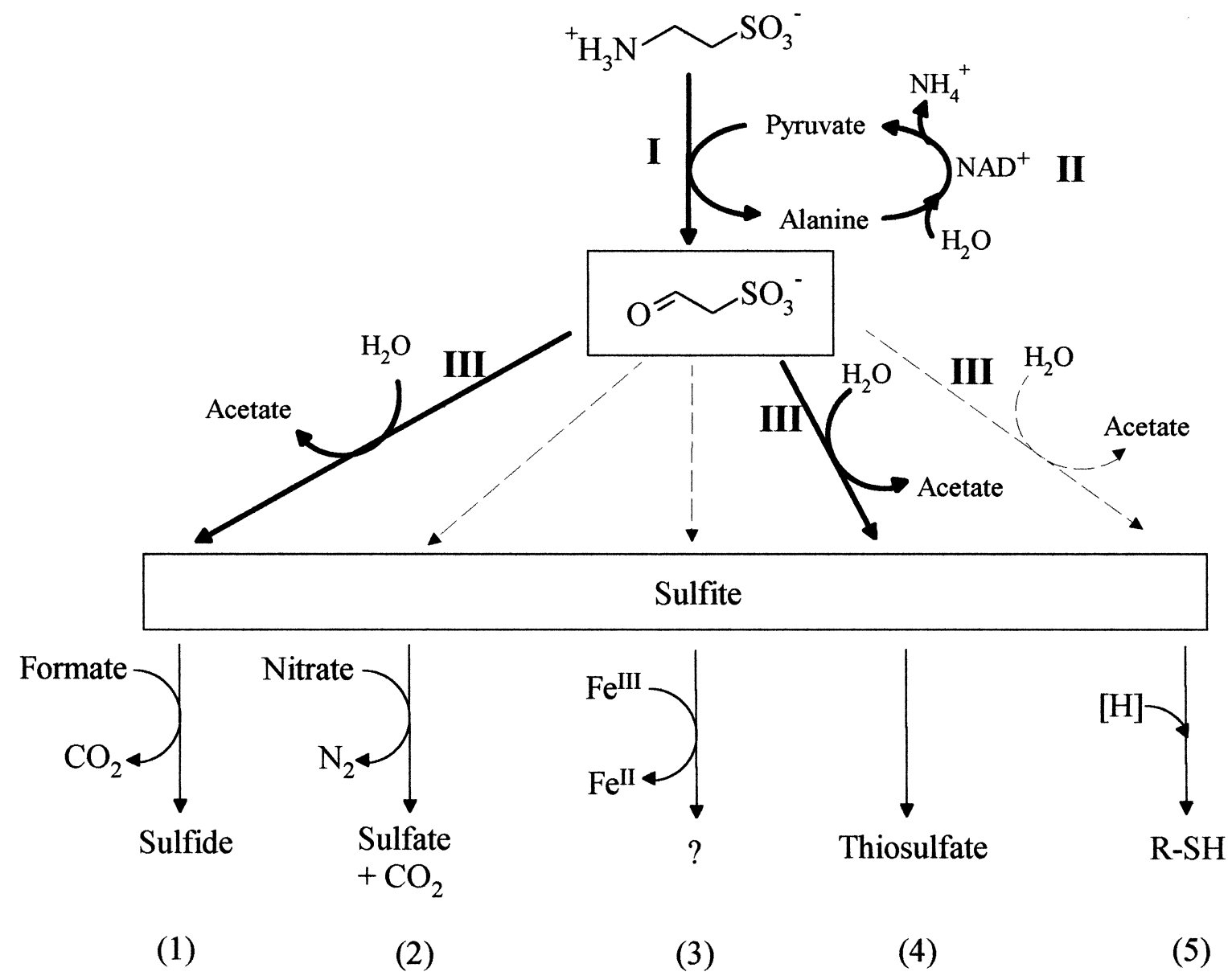

Fig. 6. Possibilities of taurine degradation by anaerobic bacteria. Enzyme I (taurine-pyruvate aminotransferase) has been detected in three anaerobic bacteria [139,149,157], enzymes II (alanine dehydrogenase) and III (sulfoacetaldehyde sulfo-lyase) in two organisms [139,149]. The pathway was thus presumed to be widespread. Taurine can participate as an electron acceptor (1), in combination with e.g. formate as an electron donor, in the anaerobic respiration of B. wadsworthia RZATAU [139]. Taurine can be utilized in anaerobic respiration (2) as an electron donor for Alcaligenes sp. strain NKNTAU concomitant with reduction of nitrate, nitrite or nitrous oxide, presumably as indicated [147], and (3) as putative electron donor for the reduction of iron(III) [148]. Fermentation of taurine (4) is the energy-conserving pathway of a newly isolated syntrophomonad, strain GKNTAU [149]. Assimilation of the sulfonate sulfur of taurine (5) can be catalyzed by many anaerobes, e.g. C. pasteurianum and C. beijerinckii EV4 [156,158], and as this reaction also involves a taurine transaminase in $C$. pasteurianum [157] a sulfoacetaldehyde sulfo-lyase (III) is surely also involved; the R-SH represents, e.g. a sulfur amino acid.

Taurine dioxygenase is encoded by tauD [55]. The gene products, $\mathrm{CysB}$ and $\mathrm{Cbl}$, were found to be crucial for the regulation of the $\operatorname{tau} A B C D$ operon, and the binding of these LysR-type transcriptional regulators to the $\operatorname{tau} A B C D$ promoter has recently been shown. CysB, a regulator of the cysteine regulon, and $\mathrm{Cbl}$, a protein with $41 \%$ sequence identity with CysB [126] are both positive regulators. CysB also functions as a positive regulator in $c b l$ expression. Furthermore, thiosulfate and sulfide act as anti-inducers of CysB-dependent transcription. In addition to taurine, the $c b l$ gene product is essential for the utilization of several other alkanesulfonates (n-alkanesulfonates $\left(\mathrm{C}_{2} \mathrm{C}_{6}\right)$, isethionate, sulfoacetate, MOPS and piperazine-1,4-bis-2-ethanesulfonate), but their degradative genes are as yet unknown. In contrast, the absence of $\mathrm{Cbl}$ leads to the disappearance of the SSI proteins normally seen under sulfate starvation conditions. Thus the $c b l$ and $c y s B$ gene products play a key role in the 
degradation of alkanesulfonates under SSI conditions.

The sulfur sources mentioned in the previous paragraph are not carbon and energy sources for $E$. coli. TauD thus does not enable $E$. coli to utilize taurine as a source of carbon. To emphasize the different metabolic regulation involved in sulfonate catabolism and assimilation of sulfonate sulfur, TS and orthanilate do not serve as sole sources of sulfur for the growth of C. testosteroni T-2 or Alcaligenes sp. strain O-1 (cf. Sections 6.3.2, 6.3.3, 6.3.4 and 6.3.5). Indeed, the cells catabolizing a sulfonate require a constant counterflux of organosulfonate for sulfite or sulfate, whereas sulfonate-assimilating cells are surely designed to capture and never to lose sulfur.

The alkanesulfonates utilized as sulfur sources by Pseudomonas aeruginosa are monooxygenated by an unknown mechanism [47], but where a comparison with catabolism is possible, as with the desulfonation of methanesulfonate, a different monooxygenation is involved ([127], cf. [56]). Algae and cyanobacteria also utilize alkanesulfonates as sulfur sources $[52,128]$.

The bacterial utilization of arenesulfonates as carbon sources is characterized by narrow substrate ranges $[37,88,129]$, one major exception being Sphingomonas sp. strain BN6 [130,131]. In contrast, the assimilation of sulfur from these compounds is characterized by the wide substrate ranges of the organisms involved; Pseudomonas putida S-313 desulfonates several hundred compounds [44,45,132], and other bacteria have similar properties $[46,129]$. Indeed, many apparently unusual compounds are subject to desulfonation $[48,132,133]$ and even to more complex transformations [134] under sulfate-limited conditions; desulfonation of a wide range of azo dyestuffs and other complex arenesulfonates has also been observed $[45,97,135]$.

In contrast to the wide range of dioxygenations involved, sometimes indirectly, in the catabolic desulfonations of aromatic compounds (Section 6.3), only one reaction-type has been detected in the SSI stimulon, apparent monooxygenation to yield the corresponding phenol [44 46]. A similar product is observed in algae which utilize naphthalenesulfonates, though further biotransformation of the naphthol can occur [136,137].

\section{Anaerobes dissimilating sulfonates as sources of carbon and energy}

Anaerobic bacteria have three possible strategies to dissimilate sulfonates: (1) as the electron acceptor; (2) as the electron donor for anaerobic respirations; or (3) as the substrate for disproportionation in fermentations. An overview of known and likely pathways of taurine utilization is shown in Fig. 6 .

\subsection{Sulfonates as electron acceptors in anaerobic respiration}

Sulfonates are utilized as electron acceptors in anaerobic respirations of sulfate-reducing bacteria $[18,138,139]$ and of non-sulfate-reducing bacteria [139].

Reduction of sulfonates as terminal electron acceptor was first discovered in Desulfovibrio desulfuricans $\mathrm{IC1}$, which was isolated from marine sediment [138]. The organism reduces the organosulfonates isethionate or cysteate in combination with lactate as electron donor. The carbon moiety of isethionate is oxidized to acetate, and electrons from the latter reaction and from lactate are used to reduce the sulfonate sulfur to sulfide. Thus, in the formal dissimilatory reaction, $1 \mathrm{~mol}$ isethionate with $1 \mathrm{~mol}$ lactate yield $1 \mathrm{~mol}$ sulfide, $2 \mathrm{~mol}$ acetate and $1 \mathrm{~mol}$ $\mathrm{CO}_{2}$ [138]. The enzymes in the desulfonation pathway have not yet been measured, but cells of strain IC1 grown with isethionate, cysteate, fumarate and sulfite contain lower specific activities of key enzymes of sulfate reduction ATP sulfurylase and APS reductase than sulfate-grown cells [18]. Another Desulfovibrio sp., strain RZACYSA, has a somewhat broader substrate range than strain IC1 (Table 1) including taurine as an electron acceptor with lactate as electron donor [139]. A wide range of sulfate-reducing bacteria is able to reduce sulfonates $[18,138]$.

Participation of taurine as electron acceptor in an anaerobic respiration was thoroughly studied in the non-sulfate-reducing bacterium Bilophila wadsworthia RZATAU. The obligately anaerobic, Gram-negative rod, that was isolated from the anaerobic digestor of a communal sewage works, utilizes taurine as the electron acceptor in the presence of e.g. formate as electron source [139]. The carbon moiety of taurine is oxidized to acetate, and electrons from the 
Table 1

Anaerobic bacteria and their dissimilation of organosulfonates as electron acceptor, electron donor or as fermentative substrate

\begin{tabular}{|c|c|c|c|c|c|c|c|c|c|}
\hline & $\begin{array}{l}\text { Bilophila } \\
\text { wads- } \\
\text { worthia }^{\mathrm{a}}\end{array}$ & $\begin{array}{l}\text { D-vibrio } \\
\text { desulfur- } \\
\text { icans }^{\mathrm{b}}\end{array}$ & $\begin{array}{l}\text { D-vibrio } \\
\text { desulfur- } \\
\text { icans }{ }^{\mathrm{c}}\end{array}$ & $\begin{array}{l}\text { D-microbium } \\
\text { baculatus }^{\mathrm{d}}\end{array}$ & $\begin{array}{l}\text { D-bacterium } \\
\text { autotroph- } \\
\text { icans }^{\mathrm{e}}\end{array}$ & $\begin{array}{l}\text { D-vibrio } \\
\text { sp. }{ }^{f}\end{array}$ & $\begin{array}{l}\text { Syn- } \\
\text { troph- } \\
\text { omonad }^{\mathrm{g}}\end{array}$ & $\begin{array}{l}\text { D-vibrio } \\
\text { sp. }\end{array}$ & $\begin{array}{l}\text { Alcaligenes } \\
\text { sp. }{ }^{\mathrm{i}}\end{array}$ \\
\hline $\begin{array}{l}\text { Electron } \\
\text { donor: }\end{array}$ & Formate & Lactate & Lactate & Lactate & Lactate & Lactate & Sulfonate & Sulfonate & Sulfonate \\
\hline $\begin{array}{l}\text { Electron } \\
\text { acceptor: }\end{array}$ & Sulfonate & Sulfonate & Sulfonate & Sulfonate & Sulfonate & Sulfonate & Sulfonate & Sulfonate & Nitrate \\
\hline Cysteate & + & + & - & + & + & + & - & + & - \\
\hline $\begin{array}{l}\text { Aminomethane- } \\
\text { sulfonate }\end{array}$ & - & $\mathrm{ND}^{1}$ & ND & ND & ND & + & - & + & - \\
\hline Ethanesulfonate & - & - & ND & ND & ND & - & - & - & - \\
\hline $\begin{array}{l}p \text {-Toluene- } \\
\text { sulfonate }\end{array}$ & - & - & ND & ND & ND & - & - & - & - \\
\hline
\end{tabular}

${ }^{\mathrm{a}}$ Bilophila wadsworthia RZATAU DSM 11045 [139].

${ }^{\mathrm{b}}$ Desulfovibrio desulfuricans IC1 [138].

${ }^{\mathrm{c}}$ Desulfovibrio desulfuricans ATCC 29577 [138].

${ }^{\mathrm{d}}$ Desulfomicrobium baculatus DSM 1741 [138].

e Desulfobacterium autotrophicans DSM 3382 [138].

${ }^{\mathrm{f}}$ Desulfovibrio $\mathrm{sp}$. strain RZACYSA [151].

latter reaction and from formate are used to reduce the sulfonate sulfur to sulfide. Thus, in the formal dissimilatory reaction, $1 \mathrm{~mol}$ taurine with 2 mol formate yield $1 \mathrm{~mol}$ each of ammonia, acetate and sulfide, and presumably 2 mol $\mathrm{CO}_{2}$ (Fig. 6 (1)). Desulfoviridin, a class of sulfite reductases, was detected in B. wadsworthia RZATAU [139]. It is believed that the activity of this sulfite reductase, reducing the liberated sulfite to sulfide, is involved in energy conservation, so sulfite reductase and other enzymes were purified to explore the overall metabolic pathway [140]. Laue et al. find enzymes of taurine transformation to be constitutive in B. wadsworthia [140]; Lie et al. observe inducible proteins (bands in SDSPAGE gels) in extracts of $D$. desulfuricans grown with different sulfonates [18].

The lower intestinal tract is the natural habitat of B. wadsworthia [141], and it is a suspected pathogen which is recovered from several different clinical specimens, especially from appendicitis [142,143]. Clinical isolates of $B$. wadsworthia utilize taurine and taurine-conjugated cholic acid derivatives [144] and it is now clear that the clinical isolates and strain RZATAU have indistinguishable growth with taurine as an electron acceptor and formate as electron donor [145]. Taurine is widespread in mammals [1],
${ }^{\mathrm{g}}$ Syntrophomonad strain GRZTAU DSM 11270 [149].

${ }^{\mathrm{h}}$ Desulfovibrio sp. strain GRZCYSA DSM 11493 [139].

${ }^{\mathrm{i}}$ Alcaligenes sp. NKNTAU DSM 11046 [147].

$\mathrm{j}+$, growth.

$\mathrm{k}-$, no growth.

${ }^{\mathrm{l}} \mathrm{ND}$, not determined.

so one suspects that its degradation (Fig. 6 (1)) is a major pathway of energy conservation of this organism in its natural habitat(s). In addition to taurine and e.g. taurocholate, B. wadsworthia utilizes cysteate and isethionate (Fig. 1), and sulfite and thiosulfate as electron acceptors; sulfate, non-activated alkanesulfonates and arenesulfonates are not ulilized [139]. The energetic advantage of reducing a sulfonate moiety in these respirations, rather than sulfate, might be that the former need not be activated in an ATP sulfurylase reaction [146].

\subsection{Sulfonates as electron donors in anaerobic respiration}

Enrichments for sulfonate-oxidizing, nitrate-reducing bacteria readily yield cultures that are able to utilize the naturally occurring, activated compounds taurine, isethionate and cysteate [147]. The facultatively anaerobic bacterium Alcaligenes sp. strain NKNTAU was examined in detail. It has a very narrow substrate range concerning sulfonates. Of 18 tested organosulfonates, the organism utilizes only taurine as a carbon and energy source for nitrate respiration. Taurine is converted quantitatively in cell material and $\mathrm{CO}_{2}$, the sulfonate moiety being 
oxidized to sulfate and the amino group released as ammonia (Fig. 6 (2)). Nitrate (nitrite or nitrous oxide) is reduced to nitrogen gas [147]. In addition to the strictly anaerobic oxidation of taurine under nitrate-reducing conditions, taurine can also be degraded by strain NKNTAU under oxic conditions. Further studies are needed to confirm that the pathway in Fig. 6 is correct and to establish whether the same enzymes are involved both in the anaerobic, nitrate-reducing and in the aerobic pathways. Another pure culture, strain NKNIS, also has a limited range of substrates as electron donor for nitrate reduction, namely isethionate and taurine. Release of sulfite in millimolar concentrations during growth of this organism indicates formation of sulfite as an intermediate during the oxidation of the sulfonate moiety [147]. A third isolate, Paracoccus denitrificans NKNCYSA, has a wider substrate range for sulfonates, and cell-free extracts transaminate cysteate to putative sulfopyruvate $[67,148]$. These preliminary data imply a degradative pathway that does not proceed via sulfoacetaldehyde [67]. Cysteate metabolism is constitutive in this organism, whereas taurine metabolism is inducible [67].
The general concept of respiration with a sulfonate as electron donor led Cook et al. to explore alternatives to nitrate as electron acceptor (Fig. 6 (3)). Cook and associates chose to work with sulfate and iron(III). Whereas they were dissatisfied with their sulfate cultures, they believe that they obtained positive enrichments with cysteate as electron donor and iron(III) as electron acceptor [67]. It is suspected that more work in this area would yield either novel organisms or novel substrates for established respirations.

\subsection{Sulfonates in fermentation}

The third strategy used by bacteria which dissimilate organosulfonates is fermentation. The first organism to be isolated, strain GKNTAU, ferments taurine. It is a strictly anaerobic, spore-forming rod which has been attributed to the Synthrophomonas assemblage within the Clostridium subdivision of Gram-positive bacteria as a presumed novel genus [149]. The organism has a narrow substrate range; of 17 tested organosulfonates and 20 non-sulfonated, fermentable compounds or autotrophic regimes, only

Table 2

Selected compounds examined as sulfur sources for growth of anaerobic bacteria

\begin{tabular}{|c|c|c|c|c|c|}
\hline & Clostridium sp. ${ }^{\mathrm{a}}$ & Clostridium spp. ${ }^{\mathrm{b}}$ & $\begin{array}{l}\text { Clostridium } \\
\text { pasteurianum }^{\text {c }}\end{array}$ & RZLAS $^{\mathrm{d}}$ & Klebsiella sp. $^{\mathrm{e}}$ \\
\hline Without sulfur & $-{ }^{\mathrm{f}}$ & \multicolumn{2}{|l|}{-} & \multicolumn{2}{|l|}{-} \\
\hline Methanesulfonate & - & - & - & - & - \\
\hline Ethanesulfonate & - & + & $\mathrm{ND}^{\mathrm{h}}$ & + & ND \\
\hline 1-Heptanesulfonate & - & + & ND & + & ND \\
\hline Cysteate & ND & ND & - & ND & + \\
\hline Benzenesulfonate & + & + & ND & ND & ND \\
\hline$p$-Sulfobenzoate & + & + & ND & ND & ND \\
\hline$p$-Toluenesulfonate & + & + & + & - & - \\
\hline 2-(4-Sulfophenyl)butyrate & + & + & ND & + & ND \\
\hline 4-Nitrocatecholsulfate & + & + & ND & ND & ND \\
\hline $\begin{array}{l}\text { a Clostridium beijerinckii EV4 } \\
{ }^{\mathrm{b}} \text { Three Clostridium } \text { spp., strai } \\
{ }^{\mathrm{c}} \text { Clostridium pasteurianum }[15 \\
\text { d Strain RZLAS }[160] .\end{array}$ & S, RZES, RZH & $\begin{array}{l}{ }^{\mathrm{e}} \mathrm{Klel} \\
\mathrm{f}_{-}, \\
{ }^{\mathrm{g}}+, \\
{ }^{\mathrm{h}} \mathrm{ND}\end{array}$ & $\begin{array}{l}\text { la sp. growing } \\
\text { rowth. } \\
\text { th. } \\
\text { t determined. }\end{array}$ & ermentativ & itions [156]. \\
\hline
\end{tabular}


taurine serves as a carbon and energy source. In contrast to the utilization of taurine as an electron acceptor in anaerobic respiration of B. wadsworthia or the oxidation of taurine by the nitrate-reducing Alcaligenes sp. strain NKNTAU, where an additional substrate (as electron donor or electron acceptor, respectively) is necessary, taurine alone suffices for growth in salts medium. The fermentation involves a transformation of the sulfonate moiety to thiosulfate as the stoichiometric product (Fig. 6 (4)). To the authors' knowledge, this is the first metabolic pathway to yield thiosulfate as an end product, despite the fact that thiosulfate is widely used in natural ecosystems as electron donor and as electron acceptor [150]. This novel end product is simultaneously a novel pathway of energy conservation.

A different isolate ferments cysteate [151]. The fermentation involves not only a different organism, but also different products from the sulfonate moiety. Strain GRZCYSA was attributed to the genus Desulfovibrio because of its substrate range, especially the ability to reduce sulfate coupled with its morphology and the presence of desulfoviridin. The sulfonate moiety of cysteate or isethionate is disproportionated to equimolar amounts of sulfate and sulfide [151]. Presumably, (a) the sulfonate moiety is released as sulfite; and (b) energy conservation during the fermentation of cysteate or isethionate is analogous to the disproportionation of sulfite to sulfate and sulfide [152]. The amino group of cysteate is recovered as ammonia and the carbon skeleton is oxidized to acetate and $\mathrm{CO}_{2}$ [151].

\subsection{Widespread reactions}

The dissimilation of taurine in aerobes has been described in some detail in two systems ([60,153]; cf. [154]) (Section 6.1) where the common reaction is the sulfoacetaldehyde sulfo-lyase. The anaerobes studied in some detail (B. wadsworthia RZATAU and strain GKNTAU) appear to have the pathway found in $P$. aeruginosa, namely a pyruvate-dependent taurine aminotransferase and a sulfo-lyase [60,139,149] (Fig. 6). The sulfo-lyase (EC 4.4.1.12) from strain GKNTAU differs in molecular properties from the only purified sulfo-lyase [57,155]. Thus, the same degradative pathway for taurine is involved in aerobes and anaerobes, the difference being the metabolic surroundings, which give different end products from the common intermediates sulfite, from the sulfonate moiety, and acetate from the carbon skeleton.

The bacteria which dissimilate organosulfonates belong largely to the broad group of sulfate reducing bacteria (Table 1). Indeed, as some of these sulfate reducers were obtained from culture collections and not by enrichment, one can deduce how widespread the anaerobic dissimilation of sulfonates must be [138]. The same conclusion was drawn from work with the phylogenetically related sulfite-reducer, Bilophila wadsworthia, as a normal part of the gut flora [139]. In contrast, the taurine-oxidizing Alcaligenes sp. strain NKNTAU belongs to a completely different group [147], and reminds one how many genera oxidize taurine aerobically (Section 6.1 ). The anaerobic oxidation of cysteate by a strain of $P$. denitrificans led to the type strain being examined. The latter organism can also oxidize at least one sulfonate anaerobically [67]. Work with the fermentation of taurine by strain GKNTAU shows that similar organisms can be found in sewage works and sediments from at least two continents [155]. The anaerobic dissimilation of sulfonates is thus widespread both geographically and phylogenetically.

\section{Anaerobes assimilating sulfonate-sulfur}

The first desulfonative anaerobes to be isolated were bacteria which utilize sulfonate-sulfur as a sulfur source [156]. Chien et al. [156] worked largely with the naturally occurring sulfonates and isolated not only the facultative anaerobe Klebsiella sp. which utilizes cysteate under fermentative conditions, but also a strain of the strict anaerobe, Clostridium pasteurianum, which utilizes taurine with the same growth yield as sulfate and isethionate and $p$-toluenesulfonate with a lower yield (Table 2). The work with $C$. pasteurianum $\mathrm{C} 1$ has been expanded to show an inducible taurine-pyruvate aminotransferase activity involved in the assimilation of taurine sulfur (Fig. 6 (5)) [157]. Although one thus expects the same reactions with taurine in assimilatory and dissimilatory growth (Fig. 6), one may also expect very different enzymes or transport systems, reflecting the different affinity for a substrate $\left(K_{\mathrm{m}}\right)$ in a dissimilatory reaction ( $K_{\mathrm{m}}$ values in the $\mathrm{mM}$ range) and 
in an assimilatory reaction ( $K_{\mathrm{m}}$ values in the $\mu \mathrm{M}$ range).

Denger et al. initially identified only strains of Clostridium in their work on arenesulfonates and alkanesulfonates $[158,159]$, but the anaerobic desulfonation is also found in an unidentified, facultatively anaerobic bacterium [160]. Growth is concomitant with substrate utilization and molar growth yields are independent of the sulfur growth substrate. In contrast to the narrow substrate ranges of dissimilatory desulfonations in anaerobes, the bacteria assimilating the sulfonate sulfur have broad substrate ranges (Table 2) similar to those of aerobic bacteria described in Section 8. Besides the naturally occurring, activated sulfonates taurine, cysteate and isethionate [156], the non-activated compounds ethanesulfonate and 1-heptanesulfonate [159] and arenesulfonates [158 160] are used as sole source of sulfur; all organisms catalyze the same arenesulfonatase reaction [160]. In contrast to Clostridium beijerinckii EV4, able to desulfonate only the activated alkanesulfonate taurine and arenesulfonates [158], three Clostridium spp. are able to utilize in addition the non-activated alkanesulfonates [159] (Table 2). This leads to the assumption that there are at least three different sulfonatase activities in these Clostridium spp.: an arenesulfonatase, a taurine desulfonating pathway and an alkanesulfonatase. The desulfonation mechanism of arenesulfonates under anaerobic conditions must be completely different from the monooxygenation in aerobic bacteria involved in assimilation of sulfur from arenesulfonates. The anaerobic mechanism has not been elucidated [159].

The substrate ranges of anaerobic bacteria able to assimilate sulfonates seem to be similar to those of aerobic bacteria. One wonders whether regulation analogous to the SSI stimulon (Section 8) will be found in anaerobes.

\section{Acknowledgments}

The authors are grateful to Colin Murrell and Michael Kertesz for information on work in progress and to Jürgen Ruff for his constructive comments on the manuscript. Work in Konstanz is being supported by the Deutsche Forschungsgemeinschaft, the University of Konstanz, ECOSOL, the Fonds der Chemischen Industrie, BASF, and the Stiftung Wohnen und Umwelt; work in Granada is being supported by the EU.

\section{References}

[1] Huxtable, R.J. (1992) Physiological actions of taurine. Physiol. Rev. 72, 101163

[2] Field, J.A., Field, T.M., Poiger, T., Siegrist, H. and Giger, W. (1995) Fate of secondary alkane sulfonate surfactants during municipal wastewater treatment. Water Res. 29, 13011307.

[3] Lange, F.T., Wenz, M. and Brauch, H.-J. (1995) Trace-level determination of aromatic sulfonates in water by on-line ionpair extraction/ion-pair chromatography and their behaviour in the aquatic environment. J. High Resolut. Chromatogr. 18, 243252.

[4] Altenbach, B. and Giger, W. (1995) Determination of benzene- and naphthalenesulfonates in wastewater by solid-phase extraction with graphitized carbon black and ion-pair liquid chromatography with UV detection. Anal. Chem. 67, 2325 2333.

[5] Bretscher, H. (1981) Waste disposal in the chemical industry. In: Microbial Metabolism of Xenobiotics and Recalcitrant Compounds (Leisinger, T., Cook, A.M., Hütter, R. and Nüesch, J., Eds.), pp. 65 74. Academic Press, London.

[6] Wellens, H. (1990) Zur biologischen Abbaubarkeit mono- und disubstituerter Benzolderivate. Z. Wasser Abwasser Forsch. 23, 8598 .

[7] Field, J.A., Leenheer, J.A., Thorn, K.A., Barber, L.B., Rostad, C., Macalady, D.L. and Daniel, S.R. (1992) Identification of persistent anionic surfactant-derived chemicals in sewage effluent and groundwater. J. Contam. Hydrol. 9, 5578.

[8] Poiger, T., Field, J.A., Field, T.M. and Giger, W. (1993) Determination of detergent-derived fluorescent whitening agents in sewage sludges by liquid chromatography. Anal. Methods Instrum. 1, 104113.

[9] Cain, R.B. (1981) Microbial degradation of surfactants and 'builder' components. In: Microbial Degradation of Xenobiotics and Recalcitrant Compounds (Leisinger, T., Cook, A.M., Hütter, R. and Nüesch, J., Eds.), pp. 323 370. Academic Press, London.

[10] Swisher, R.D. (1987) Surfactant Biodegradation, 2nd edn. Marcel Dekker, New York, NY.

[11] Soeder, C., Luther, M. and Kneifel, H. (1988) Abbaupotential von Mikroalgen unter besonderer Berücksichtigung der Desulfonierung aromatischer Sulfonsäuren. GWF Gas Wasserfach Wasser Abwasser 129, 8285.

[12] Painter, H.A. and Mosey, F.E. (1992) The anaerobic biodegradability of linear alkyl benzene sulfonate (LAS). 3rd CESIO Internat. Surfact. Cong. pp. 34 43, London, UK, June, $0105,1992$.

[13] Hooper, S.W. (1994) Biodegradation of sulfonated aromatics. In: Biological Degradation and Bioremediation of Toxic Chemicals (Chaudhry, G.R., Ed.), pp. 169 182. Chapman and Hall, London. 
[14] Seitz, A.P. and Leadbetter, E.R. (1995) Microbial assimilation and dissimilation of sulfonate sulfur. ACS Symp. Ser. 612, 365375.

[15] Kelly, D.P. (1996) Perspectives in the microbiology of atmospheric trace gases. In: Microbiology of Atmospheric Trace Gases: Sources, Sinks and Global Change Processes (Murrell, J.C. and Kelly, D.P. Eds.), pp. 288 295. Springer, Berlin.

[16] Kelly, D.P. and Murrell, J.C. (1996) Metabolism of methanesulfonic acid. In: Microbial Growth on $\mathrm{C}_{1}$ Compounds (Lidstrom, M.E. and Tabita, F.R., Eds.), pp. 33 40. Kluwer, Dordrecht.

[17] Cook, A.M. (1998) Sulfonated surfactants and related compounds: facets of their desulfonation by aerobic and anaerobic bacteria. Tenside Surfact. Deterg. 35, 5256.

[18] Lie, T.L., Leadbetter, J.R. and Leadbetter, E.R. (1998) Metabolism of sulfonic acids and other organosulfur compounds by sulfate-reducing bacteria. Geomicrobiol. J. 15, 135149.

[19] Dodgson, K.S., White, G.F. and Fitzgerald, J.W. (1982) Sulfatases of Microbial Origin. CRC Press, Boca Raton, FL.

[20] Higgins, T.P., Snape, J.R. and White, G.F. (1993) Comparison of pathways for biodegradation of monomethyl sulphate in Agrobacterium and Hyphomicrobium species. J. Gen. Microbiol. 139, 29152920.

[21] Liebman, J.F. (1991) Thermochemistry of sulphonic acids and their derivatives. In: The Chemistry of Sulphonic Acids, Esters and their Derivatives (Patai, S. and Rappoport, Z., Eds.), pp. 283 321. Wiley, Chichester.

[22] Koechlin, B.A. (1954) The isolation and identification of the major anion fraction of the axoplasm of squid giant nerve fibers. Proc. Natl. Acad. Sci. USA 40, 6062.

[23] Frank, P., Hedman, B., Carlson, R.M.K., Tyson, T.A., Roe, A.L. and Hogson, K.O. (1987) A large reservoir of sulfate and sulfonate residues within plasma cells from Ascidia ceratodes, revealed by X-ray absorption near-edge structure spectroscopy. Biochemistry 26, 49754979.

[24] Vairavamurthy, A., Manowitz, B., Luther III, G.W. and Jeon, Y. (1993) Oxidation state of sulfur in thiosulfate and implications for anaerobic energy metabolism. Geochim. Cosmochim. Acta 57, 16191623.

[25] Autry, A.R. and Fitzgerald, J.W. (1990) Sulfonate S: a major form of forest soil organic sulfur. Biol. Fertil. Soils 10, 5056.

[26] Vairamurthy, A., Zhou, W., Eglinton, T. and Manowitz, B. (1994) Sulfonates: a new class of organic sulfur compounds in marine sediments. Geochim. Cosmochim. Acta 58, 4681 4687.

[27] van Loon, W.M.G.M., Boon, J.J. and de Groot, B. (1993) Quantitative analysis of sulfonic acid groups in macromolecular lignosulfonic acids and aquatic humic substances by temperature-resolved pyrolysis-mass spectrometry. Environ. Sci. Technol. 27, 23872396.

[28] Stevenson, F.J. (1996) Humus Chemistry: Genesis Composition Reactions. Wiley, New York.

[29] Strickland, T.C., Fitzgerald, J.W. and Swank, W.T. (1986) In situ measurements of sulfate incorporation into forest floor and soil organic matter. Can. J. For. Res. 16, 549553.

[30] Novak, M., Bottrell, S.H., Fottova, D., Buzek, F., Groscheova, H. and Zak, K. (1996) Sulfur isotope signals in forest soils of central Europe along an air pollution gradient. Environ. Sci. Technol. 30, 34733476.

[31] White, R.H. (1986) Intermediates in the biosynthesis of coenzyme M (2-mercaptoethanesulfonic acid). Biochemistry 25, 53045308

[32] Pugh, C.E., Roy, A.B., Hawkes, T. and Harwood, J.L. (1995) A new pathway for the synthesis of the plant sulpholipid, sulphoquinovosyldiacylglycerol. Biochem. J. 309, 513519.

[33] Pawlenko, S. (1985) Sulfonsäuren und deren Derivate. In: Methoden der Organischen Chemie (Houben-Weyl) (Klamann, D., Ed.), 4th edn., vol. E11, pp. 1055 1060. Thieme, Stuttgart.

[34] Kim, I.S., Sasinos, F.I., Stephens, R.D. and Brown, M.A. (1990) Anion-exchange chromatography particle beam mass spectrometry for the characterization of aromatic sulfonic acids as the major organic pollutants in leachates from Stringfellow, California. Environ. Sci. Technol. 24, 1832 1836.

[35] Altenbach, B. (1996) PhD Thesis. Determination of substituted benzene- and naphthalenesulfonates in waste water and their behaviour in sewage treatment. Swiss Federal Institute of Technology, Zürich, Switzerland.

[36] Field, J.A. and Thurman, E.M. (1996) Glutathione conjugation and contaminant transformation. Environ. Sci. Technol. 30, 14131418.

[37] Thurnheer, T., Köhler, T., Cook, A.M. and Leisinger, T. (1986) Orthanilic acid and analogues as carbon sources for bacteria: growth physiology and enzymic desulphonation. J. Gen. Microbiol. 132, 12151220.

[38] Johnston, J.B., Murray, K. and Cain, R.B. (1975) Microbial metabolism of aryl sulphonates. A reassessment of colorimetric methods for the determination of sulphite and their use in measuring desulphonation of aryl and alkylbenzene sulphonates. Antonie van Leeuwenhoek 41, 493511.

[39] Thiele, B., Günther, K. and Schwuger, M.J. (1998) Spurenanalytik von Tensiden. Anal. Taschenbuch 18, 4566.

[40] Benson, A.A. (1963) The plant sulfolipid. Adv. Lipid Res. 1, 387394.

[41] Locher, H.H., Leisinger, T. and Cook, A.M. (1991) 4-Sulphobenzoate 3,4-dioxygenase: purification and properties of a desulphonative two-component enzyme system from Comamonas testosteroni T-2. Biochem. J. 274, 833842.

[42] Fuchs, G., Mohamed, M.E.S., Altenschmidt, U., Koch, J., Lack, A., Brackmann, R., Lochmeyer, C. and Oswald, B. (1994) Biochemistry of anaerobic biodegradation of aromatic compounds. In: Biochemistry of Microbial Degradation (Ratledge, C., Ed.), pp. 513 553. Kluwer, Dordrecht.

[43] Locher, H.H., Leisinger, T. and Cook, A.M. (1989) Degradation of $p$-toluenesulphonic acid via sidechain oxidation, desulphonation and meta ring cleavage in Pseudomonas (Comamonas) testosteroni T-2. J. Gen. Microbiol. 135, 19691978.

[44] Zürrer, D., Cook, A.M. and Leisinger, T. (1987) Microbial desulfonation of substituted naphthalenesulfonic acids and benzenesulfonic acids. Appl. Environ. Microbiol. 53, 1459 1463.

[45] Kertesz, M.A., Kölbener, P., Stockinger, H., Beil, S. and Cook, A.M. (1994) Desulfonation of linear alkylbenzenesulfo- 
nate surfactants and related compounds by bacteria. Appl. Environ. Microbiol. 60, 22962303.

[46] Dudley, M.W. and Frost, J.W. (1994) Biocatalytic desulfurization of arylsulfonates. Bioorg. Med. Chem. 2, 681690.

[47] Kertesz, M.A. (1996) Desulfonation of aliphatic sulfonates by Pseudomonas aeruginosa PAO. FEMS Microbiol. Lett. 137, 221225.

[48] Laue, H., Field, J.A. and Cook, A.M. (1996) Bacterial desulfonation of the ethanesulfonate metabolite of the chloroacetanilide herbicide metazachlor. Environ. Sci. Technol. 30, 1129 1132.

[49] King, J.F. (1991) Acidity. In: The Chemistry of Sulphonic Acids, Esters and their Derivatives (Patai, S. and Rappoport, Z., Eds.), pp. 249 258. Wiley, Chichester.

[50] Biedlingmaier, S. and Schmidt, A. (1986) Characterization of the non-constitutive ethanesulfonate uptake in Chlorella fusca. Biochim. Biophys. Acta 861, 95104.

[51] Biedlingmaier, S. and Schmidt, A. (1987) Uptake and metabolism of taurine in the green alga Chlorella fusca. Physiol. Plant. 70, 688696.

[52] Biedlingmaier, S. and Schmidt, A. (1987) Uptake and utilization of sulfonic acids in the cyanobacterial strains Anabaena variabilis and Plectonema 73110. Z. Naturforsch. C: Biosci. 42c, 891896.

[53] Thurnheer, T., Zürrer, D., Höglinger, O., Leisinger, T. and Cook, A.M. (1990) Initial steps in the degradation of benzene sulfonic acid, 4-toluene sulfonic acid and orthanilic acid in Alcaligenes sp. strain O-1. Biodegradation 1, 5564.

[54] Locher, H.H., Poolman, B., Cook, A.M. and Konings, W.N. (1993) Uptake of 4-toluene sulfonate by Comamonas testosteroni T-2. J. Bacteriol. 175, 10751080.

[55] van der Ploeg, J.R., Weiss, M., Saller, E., Nashimoto, H., Saito, N., Kertesz, M.A. and Leisinger, T. (1996) Identification of sulfate starvation-regulated genes in Escherichia coli: a gene cluster involved in the utilization of taurine as a sulfur source. J. Bacteriol. 178, 54385446.

[56] Higgins, T.P., de Marco, P. and Murrell, J.C. (1997) Purification and molecular characterization of the electron transport protein of methanesulfonic acid monooxygenase. J. Bacteriol. 179, 19741979.

[57] Kondo, H. and Ishimoto, M. (1975) Purification and properties of sulfoacetaldehyde sulfo-lyase, a thiamine pyrophosphate-dependent enzyme forming sulfite and acetate. J. Biochem. 78, 317325 .

[58] Shimamoto, G. and Berk, R.S. (1980) Taurine catabolism II. Biochemical and genetic evidence for sulfoacetaldehyde sulfolyase involvement. Biochim. Biophys. Acta 632, 121130.

[59] Shimamoto, G. and Berk, R.S. (1980) Taurine catabolism III. Evidence for the participation of the glyoxylate cycle. Biochim. Biophys. Acta 632, 399407.

[60] Shimamoto, G. and Berk, R.S. (1979) Catabolism of taurine in Pseudomonas aeruginosa. Biochim. Biophys. Acta 569, 287 292.

[61] Kondo, H. and Ishimoto, M. (1987) Taurine dehydrogenase. Methods Enzymol. 143, 496499.

[62] King, J.E., Jaouhari, R. and Quinn, J.P. (1997) The role of sulfoacetaldehyde sulfo-lyase in the mineralization of isethio- nate by an environmental Acinetobacter isolate. Microbiology 143, 23392343.

[63] Kondo, H., Niki, H., Takahashi, S. and Ishimoto, M. (1977) Enzymatic oxidation of isethionate to sulfoacetaldehyde in bacterial extract. J. Biochem. 81, 19111916.

[64] King, J.E. and Quinn, J.P. (1997) Metabolism of sulfoacetate by environmental Aureobacterium sp. and Comamonas acidovorans isolates. Microbiology 143, 23392343.

[65] Stapley, E.O. and Starkey, R.L. (1970) Decomposition of cysteic acid and taurine by soil microorganisms. J. Gen. Microbiol. 64, 7784 .

[66] Braun, R. and Fromageot, P. (1962) Désamination de la taurine par Aspergillus niger. Biochim. Biophys. Acta 62, 548 555.

[67] Mikosch, C., Denger, K. and Cook, A.M. (1998) Anaerobic oxidation of cysteate, unpublished data.

[68] Thysse, G.J.E. and Wanders, T.H. (1974) Initial steps in the degradation of $n$-alkane-1-sulphonates by Pseudomonas. Antonie van Leeuwenhoek 40, 2537.

[69] Baker, S.C., Kelly, D.P. and Murrell, J.C. (1991) Microbial degradation of methanesulphonic acid: a missing link in the biogeochemical sulphur cycle. Nature 350, 627628.

[70] Thompson, A.S., Owens, N.J.P. and Murrell, J.C. (1995) Isolation and characterization of methanesulfonic acid-degrading bacteria from the marine environment. Appl. Environ. Microbiol. 61, 23882393.

[71] Kelly, D.P., Baker, S.C., Trickett, J., Davey, M. and Murrell, J.C. (1994) Methylsulfonate utilization by a novel methylotrophic bacterium involves an unusual monooxygenase. Microbiology 140, 14191426.

[72] Higgins, T.P., Davey, M., Trickett, J., Kelly, D.P. and Murrell, J.C. (1996) Metabolism of methanesulfonic acid involves a multicomponent monooxygenase enzyme. Microbiology 142, 251260.

[73] Butler, C.S. and Mason, J.R. (1997) Structure function analysis of the bacterial aromatic ring hydroxylating dioxygenases. Adv. Microb. Physiol. 38, 4784.

[74] Kauppi, B., Lee, K., Carredano, F., Parales, R.E., Gibson, D.T., Eklund, H. and Ramaswamy, S. (1998) Structure of an aromatic-ring-hydroxylating dioxygenase naphthalene 1,2-dioxygenase. Structure 6, 571586.

[75] Holmes, A.J., Kelly, D.P., Baker, S.C., Thompson, A.S., de Marco, P., Kenna, A.M. and Murrell, J.C. (1997) Methylosulfonomonas methylovora gen. nov., sp. nov., and Marinosulfomonas methylotropha gen. nov., sp. nov. :novel methylotrophs able to grow on methylsulfonic acid. Arch. Microbiol. 167, 4653.

[76] Quick, A., Russell, N.J., Hales, S.G. and White, G.F. (1994) Biodegradation of sulphosuccinate: direct desulphonation of a secondary sulphonate. Microbiology 140, 29912998.

[77] Wittich, R.M., Rast, H.G. and Knackmuss, H.-J. (1988) Degradation of naphthalene-2,6- and naphthalene-1,6-disulfonic acid by a Moraxella sp. Appl. Environ. Microbiol. 54, 1842 1847.

[78] Endo, K., Kondo, H. and Ishimoto, M. (1977) Degradation of benzenesulfonate to sulfite in bacterial extract. J. Biochem. 82, 13971402. 
[79] Brilon, C., Beckmann, W. and Knackmuss, H.-J. (1981) Catabolism of naphthalenesulfonic acids by Pseudomonas sp. A3 and Pseudomonas sp. C22. Appl. Environ. Microbiol. 42, 44 55.

[80] Nörtemann, B., Baumgarten, J., Rast, H.G. and Knackmuss, H.-J. (1986) Bacterial communities degrading amino- and hydroxynaphthalene-2-sulfonates. Appl. Environ. Microbiol. 52, 11951202.

[81] Heiss, G., Muller, C., Altenbuchner, J. and Stolz, A. (1997) Analysis of a new dimeric extradiol dioxygenase from a naphthalenesulfonate-degrading sphingomonad. Microbiology 143, 16911699.

[82] Batie, C.J., Ballou, D.P. and Correll, C.C. (1991) Phthalate dioxygenase reductase and related flavin iron sulfur containing electron transferases. In: Chemistry and Biochemistry of Flavoenzymes (Müller, F., Ed.), vol. 3, pp. 543 556. CRC Press, Boca Raton, FL.

[83] Powlowski, J. and Shingler, V. (1994) Genetics and biochemistry of phenol degradation by Pseudomonas sp. CF600. Biodegradation 5, 219236.

[84] Shanklin, J., Whittle, E. and Fox, B.G. (1994) Eight histidine residues are catalytically essential in a membrane-associated iron enzyme, stearoyl-CoA desaturase, and are conserved in alkane hydroxylase and xylene monooxygenase. Biochemistry 33, 1278712794.

[85] Junker, F., Leisinger, T. and Cook, A.M. (1994) 3-Sulphocatechol 2,3-dioxygenase and other dioxygenases (EC 1.13.11.2 and EC 1.14.12.-) in the degradative pathways of 2-aminobenzenesulphonic, benzenesulphonic and 4-toluenesulphonic acids in Alcaligenes sp. strain O-1. Microbiology 140, 1713 1722 .

[86] Junker, F., Field, J.A., Bangerter, F., Ramsteiner, K., Kohler, H.-P., Joannou, C.L., Mason, J.R., Leisinger, T. and Cook, A.M. (1994) Oxygenation and spontaneous deamination of 2-aminobenzenesulphonic acid in Alcaligenes sp. strain O-1 with subsequent meta ring cleavage and spontaneous desulphonation to 2-hydroxymuconic acid. Biochem. J. 300, 429 436.

[87] Ripin, M.J., Nook, K.F. and Cook, T.M. (1971) Bacterial metabolism of aryl sulphonates. 1. Benzene sulphonate as a growth substrate for Pseudomonas testosteroni H-8. Appl. Environ. Microbiol. 21, 495499.

[88] Balashov, S.V. and Boronin, A.M. (1996) Sewage-sludge bacterial isolates decomposing sulfoaromatic compounds. Microbiology (Mikrobiologiya) 65, 627631 .

[89] Balashov, S.V. and Boronin, A.M. (1997) Benzenesulphonic and $p$-toluenesulphonic acid degrading plasmids of Comamonas testosteroni. Russ. J. Genet. 33, 498503.

[90] Locher, H.H., Leisinger, T. and Cook, A.M. (1991) 4-Toluene sulfonate methyl-monooxygenase from Comamonas testosteroni T-2: purification and some properties of the oxygenase component. J. Bacteriol. 173, 37413748.

[91] Junker, F., Kiewitz, R. and Cook, A.M. (1997) Characterization of the $p$-toluenesulfonate operon $t s a M B C D$ and $t s a R$ in Comamonas testosteroni T-2. J. Bacteriol. 179, 919927.

[92] Junker, F., Saller, E., Schläfli Oppenberg, H.R., Kroneck, P.M.H., Leisinger, T. and Cook, A.M. (1996) Degradative pathways for $p$-toluenecarboxylate and $p$-toluenesulfonate and their multi-component oxygenases in Comamonas testosteroni strains PSB-4 and T-2. Microbiology 142, 2419 2427.

[93] Schläfli Oppenberg, H.R., Chen, G., Leisinger, T. and Cook, A.M. (1995) Regulation of the degradative pathways from 4-toluenesulphonate and 4-toluenecarboxylate to protocatechuate in Comamonas testosteroni T-2. Microbiology 141, 18911899.

[94] Junker, F. and Cook, A.M. (1997) Conjugative plasmids and the degradation of arylsulfonates in Comamonas testosteroni. Appl. Environ. Microbiol. 63, 24032410.

[95] Tralau, T. (1997) Diplomarbeit. Charakterisierung von Plasmid pTSA und von Plasmiden aus der Umwelt, welche katabolische Gene des Toluolsulfonatabbaus tragen. University of Konstanz.

[96] Schell, M.A. (1993) Molecular biology of the LysR family of transcriptional regulators. Annu. Rev. Microbiol. 47, 597 626.

[97] Ruff, J. and Cook, A.M. (1998) unpublished data.

[98] Wyndham, R.C., Cashore, A.E., Nakatsu, C.H. and Peel, M.C. (1994) Catabolic transposons. Biodegradation 5, 323 342 .

[99] Kölbener, P., Baumann, U., Leisinger, T. and Cook, A.M. (1995) Non-degraded metabolites arising from the biodegradation of commercial linear alkylbenzenesulfonate (LAS) surfactants in a laboratory trickling filter. Environ. Toxicol. Chem. 14, 561569.

[100] Focht, D.D. and Williams, F.D. (1970) The degradation of p-toluenesulphonate by a Pseudomonas. Can. J. Microbiol. 16, 309316.

[101] Mampel, J. (1997) Diplomarbeit. Reinigung und Charakterisierung des Orthanilat-Dioxygenase-Systems in Alcaligenes sp. Stamm O-1. University of Konstanz.

[102] Jahnke, M., El-Banna, T., Klintworth, R. and Auling, G. (1990) Mineralization of orthanilic acid is a plasmid-associated trait in Alcaligenes sp. O-1. J. Gen. Microbiol. 136, 22412249.

[103] Jahnke, M., Lehmann, F., Schoebel, A. and Auling, G. (1993) Transposition of the TOL catabolic genes (Tn4651) into the degradative plasmid pSAH of Alcaligenes sp. O-1 ensures simultaneous mineralization of sulpho- and methylsubstituted aromatics. J. Gen. Microbiol. 139, 19591966.

[104] Hammer, A., Stolz, A. and Knackmuss, H.-J. (1996) Purification and characterization of a novel type of protocatechuate 3,4-dioxygenase with the ability to oxidize 4-sulfocatechol. Arch. Microbiol. 166, 92100.

[105] Feigel, B.J. and Knackmuss, H.-J. (1988) Bacterial catabolism of sulfanilic acid via catechol-4-sulfonic acid. FEMS Microbiol. Lett. 55, 113118.

[106] Feigel, B.J. and Knackmuss, H.-J. (1993) Syntrophic interactions during degradation of 4-aminobenzenesulfonic acid by a two species bacterial culture. Arch. Microbiol. 159, 124130.

[107] Contzen, M., Wittich, R.-M., Knackmuss, H.-J. and Stolz, A. (1996) Degradation of benzene 1,3-disulfonate by a mixed bacterial culture. FEMS Microbiol. Lett. 136, 4550. 
[108] Schulz, S. (1998) Diplomarbeit. Der Abbauweg von 2-(4-Sulfophenyl)butyrat als Kohlenstoff-und Energiequelle für aerobe Bakterien. University of Konstanz.

[109] Thurnheer, T., Cook, A.M. and Leisinger, T. (1988) Co-culture of defined bacteria to degrade seven sulfonated aromatic compounds: efficiency, rates and phenotypic variations. Appl. Microbiol. Biotechnol. 29, 605609.

[110] Kölbener, P., Baumann, U., Cook, A.M. and Leisinger, T. (1994) 3-Nitrobenzenesulfonic acid and 3-aminobenzensulfonic acid in a laboratory trickling filter: biodegradability with different activated sludges. Water Res. 28, 18551860.

[111] Locher, H.H., Thurnheer, T., Leisinger, T. and Cook, A.M. (1989) 3-Nitrobenzenesulfonate, 3-aminobenzenesulfonate and 4-aminobenzenesulfonate as sole carbon sources for bacteria. Appl. Environ. Microbiol. 55, 492494.

[112] Paszczynski, A., Pastigrigsby, M.B., Goszczynski, S., Crawford, R.L. and Crawford, D.L. (1992) Mineralization of sulfonated azo dyes and sulfanilic acid by Phanerochaete chrysosporium and Streptomyces chromofuscus. Appl. Environ. Microbiol. 58, 35983604.

[113] Muralikrishna, C. and Renganathan, V. (1993) Peroxidasecatalyzed desulfonation of 3,5-dimethyl-4-hydroxy- and 3,5dimethyl-4-aminobenzenesulfonic acids. Biochem. Biophys. Res. Commun. 1197, 798804.

[114] Goszczynski, S., Paszczynski, A., Pasti-Grigsby, M.B., Crawford, R.L. and Crawford, D.L. (1994) New pathway for degradation of sulfonated azo dyes by microbial peroxidases of Phanerochaete chrysosporium and Streptomyces chromofuscus. J. Bacteriol. 176, 13391347.

[115] Kirk, T.K. and Farrell, R.L. (1987) Enzymatic 'combustion': the microbial degradation of lignin. Annu. Rev. Microbiol. 41, 465505.

[116] Kertesz, M.A., Cook, A.M. and Leisinger, T. (1994) Microbial metabolism of sulfur- and phosphorus-containing xenobiotics. FEMS Microbiol. Rev. 15, 195215.

[117] Kertesz, M.A., Leisinger, T. and Cook, A.M. (1993) Proteins induced by sulfate limitation in Escherichia coli, Pseudomonas putida, or Staphylococcus aureus. J. Bacteriol. 175, 1187 1190.

[118] Quadroni, M., Staudenmann, W., Kertesz, M. and James, P. (1996) Analysis of global responses by protein and peptide fingerprinting of proteins isolated by two-dimensional gel electrophoresis. Application to the sulfate-starvation response of Escherichia coli. Eur. J. Biochem. 239, 773 781.

[119] Hummerjohann, J., Küttel, E., Quadroni, M., Leisinger, T. and Kertesz, M.A. (1998) Regulation of the sulfate starvation response in Pseudomonas aeruginosa: role of cysteine biosynthetic intermediates. Microbiology 144, 13751386.

[120] Seitz, A.P., Leadbetter, E.R. and Godchaux III, W. (1993) Utilization of sulfonates as sole sulfur source by soil bacteria including Comamonas acidovorans. Arch. Microbiol. 159, 440444.

[121] Uria-Nickelsen, M.R., Leadbetter, E.R. and Godchaux III, W. (1993) Sulfonate utilization by enteric bacteria. J. Gen. Microbiol. 139, 203208.

[122] Uria-Nickelsen, M.R., Leadbetter, E.R. and Godchaux III,
W. (1993) Sulfonate-sulfur assimilation by yeasts resembles that of bacteria. FEMS Microbiol. Lett. 114, 7378.

[123] Uria-Nickelson, M.R., Godchaux III, W. and Leadbetter, E.R. (1994) Comparative aspects of utilization of sulfonate and other sulfur sources by Escherichia coli K12. Arch. Microbiol. 161, 434438.

[124] Uria-Nickelsen, M.R., Leadbetter, E.R. and Godchaux III, W. (1994) Sulfonate-sulfur utilization involves a portion of the assimilatory sulfate reduction pathway in Escherichia coli. FEMS Microbiol. Lett. 123, 4348.

[125] Eichhorn, E., van der Ploeg, J.R., Kertesz, M.A. and Leisinger, T. (1997) Characterization of $\alpha$-ketoglutarate-dependent taurine dioxygenase from Escherichia coli. J. Biol. Chem. 272, 2303123036.

[126] van der Ploeg, J.R., Iwanicka-Nowicka, R., Kertesz, M.A., Leisinger, T. and Hryniewicz, M.H. (1997) Involvement of the $\mathrm{CysB}$ and $\mathrm{Cbl}$ regulatory proteins in expression of the tau $A B C D$ operon and other sulfate-starvation-inducible genes in Escherichia coli. J. Bacteriol. 179, 76717678.

[127] Kertesz, M.A., Rist, W., Schmidt-Larbig, K. and Wüest, T. (1998) A novel $\mathrm{FMNH}_{2}$-dependent methanesulfonate monooxygenase encoded by the sulfur-regulated $m s u$ operon of Pseudomonas aeruginosa. unpublished data.

[128] Biedlingmaier, S. and Schmidt, A. (1983) Alkylsulfonic acids and some S-containing detergents as sulfur sources for growth of Chlorella fusca. Arch. Microbiol. 136, 124130.

[129] King, J.E. and Quinn, J.P. (1997) The utilization of organosulphonates by soil and freshwater bacteria. Lett. Appl. Microbiol. 24, 474478.

[130] Nörtemann, B., Kuhm, A.E., Knackmuss, H.-J. and Stolz, A. (1994) Conversion of substituted naphthalenesulfonates by Pseudomonas sp. BN6. Arch. Microbiol. 161, 320327.

[131] Haug, W., Schmidt, A., Nörtemann, B., Hempel, D.C., Stolz, A. and Knackmuss, H.J. (1991) Mineralization of the sulfonated azo dye Mordant Yellow 3 by a 6-aminonaphthalene-2-sulfonate-degrading bacterial consortium. Appl. Environ. Microbiol. 57, 31443149.

[132] Mampel, J., Hitzler, T., Ritter, A. and Cook, A.M. (1998) Desulfonation of the biotransformation products from commercial linear alkylbenzenesulfonates (LAS). Environ. Toxicol. Chem. 17, in press.

[133] Rein, U., Mampel, J. and Cook, A.M. (1998) Bacterial cleavage of nitrogen to sulfone bonds in sulfamide and $1 H-2,1,3-$ benzothiadiazin-4(3H)-one 2,2-dioxide: formation of 2-nitrobenzamide by Gordonia sp. unpublished data.

[134] Key, B.D., Howell, R.D. and Criddle, C.S. (1998) Defluorinationof organofluorine sulfur compounds by Pseudomonas sp. strain S2. Environ. Sci. Technol. 32, 22832287.

[135] Hitzler, T. and Cook, A.M. (1996) unpublished data.

[136] Soeder, C.J., Hegewald, E. and Kneifel, H. (1987) Green microalgae can use naphthalenesulfonic acids as sources of sulfur. Arch. Microbiol. 148, 260263.

[137] Kneifel, H., Elmendorff, K., Hegewald, E. and Soeder, C.J. (1997) Biotransformation of 1-naphthalenesulfonic acid by the green alga Scenedesmus obliquus. Arch. Microbiol. 167, 3237.

[138] Lie, T.J., Pitta, T., Leadbetter, E.R., Godchaux III, W. and 
Leadbetter, J.R. (1996) Sulfonates: novel electron acceptors in anaerobic respiration. Arch. Microbiol. 166, 204210.

[139] Laue, H., Denger, K. and Cook, A.M. (1997) Taurine reduction in anaerobic respiration of Bilophila wadsworthia RZATAU. Appl. Environ. Microbiol. 63, 20162021.

[140] Laue, H. and Cook, A.M. (1998) unpublished data.

[141] Baron, E.J., Summanen, P., Downes, J., Roberts, M.C., Wexler, H. and Finegold, S.M. (1989) Bilophila wadsworthia, gen. nov. and sp. nov., a unique Gram-negative anaerobic rod recovered from appendicitis specimens and human faeces. J. Gen. Microbiol. 135, 34053411.

[142] Finegold, S., Summanen, P., Hunt Gerardo, S. and Baron, E. (1992) Clinical importance of Bilophila wadsworthia. Eur. J. Clin. Microbiol. Inf. Dis. 11, 10581063.

[143] Schumacher, U.K., Eiring, P. and Häcker, F.-M. (1997) Incidence of Bilophila wadsworthia in appendiceal, peritoneal and faecal samples of children. Clin. Microbiol. Infect. 3, 134136 .

[144] Schumacher, U.K., Lutz, F. and Werner, H. (1996) Taurine and taurine conjugated bile acids enhance growth of Bilophila wadsworthia. 21st International Congress on Microbial Ecology and Disease, Paris, pp. 2830 October 1996.

[145] Laue, H., Schumacher, U.K. and Cook, A.M. (1998) Taurine reduction powers rapid growth of Bilophila wadsworthia. Anaerobe, submitted for publication.

[146] Dahl, C., Koch, H.-G., Keuken, O. and Trüper, H.G. (1990) Purification and characterization of ATP sulfurylase from the extremely thermophilic archaebacterial sulfate-reducer, Archaeoglobus fulgidus. FEMS Microbiol. Lett. 67, 2732.

[147] Denger, K., Laue, H. and Cook, A.M. (1997) Anaerobic taurine oxidation: a novel reaction by a nitrate-reducing $\mathrm{Al}$ caligenes sp. Microbiology 143, 19191924.

[148] Mikosch, C. (1997) Diplomarbeit. Anaerobe mikrobielle Oxidation sulfonierter Verbindungen. University of Konstanz.

[149] Denger, K., Laue, H. and Cook, A.M. (1997) Thiosulfate as a metabolic product: the bacterial fermentation of taurine. Arch. Microbiol. 168, 297301.

[150] Jørgensen, B.B. (1990) A thiosulfate shunt in the sulfur cycle of marine sediments. Science 249, 152154.

[151] Laue, H., Denger, K. and Cook, A.M. (1997) Fermentation of cysteate by a sulfate-reducing bacterium. Arch. Microbiol. $168,210214$.

[152] Bak, F. and Cypionka, H. (1987) A novel type of energy metabolism involving fermentation of inorganic sulfur compounds. Nature 326, 891892.

[153] Kondo, H., Anada, H., Ohsawa, K. and Ishimoto, M. (1971) Formation of sulfoacetaldehyde from taurine in bacterial extracts. J. Biochem. 69, 621623.

[154] Toyama, S., Miyasato, K., Yasuda, M. and Soda, K. (1973) Occurrence of taurine-pyruvate aminotransferase in bacterial extract. Agric. Biol. Chem. 37, 29392941.

[155] Denger, K. and Cook, A.M. (1998) unpublished data.
[156] Chien, C.-C., Leadbetter, E.R. and Godchaux III, W. (1995) Sulfonate-sulfur can be assimilated for fermentative growth. FEMS Microbiol. Lett. 129, 189194.

[157] Chien, C.-C., Leadbetter, E.R. and Godchaux III, W. (1997) Taurine-sulfur assimilation and taurine-pyruvate aminotransferase activity in anaerobic bacteria. Appl. Environ. Microbiol. 63, 30213024.

[158] Denger, K., Kertesz, M.A., Vock, E.H., Schön, R., Mägli, A. and Cook, A.M. (1996) Anaerobic desulfonation of 4-tolylsulfonate and 2-(4-sulfophenyl)butyrate by a Clostridium sp. Appl. Environ. Microbiol. 62, 15261530.

[159] Denger, K. and Cook, A.M. (1997) Assimilation of sulfur from alkyl- and arylsulfonates by Clostridium spp. Arch. Microbiol. 167, 177181.

[160] Denger, K. and Cook, A.M. (1998) Linear alkylbenzenesulfonate (LAS) bioavailable to anaerobic bacteria as a source of sulfur. J. Appl. Microbiol., in press.

[161] White, R.H. (1988) Characterization of the enzymatic conversion of sulfoacetaldehyde and L-cysteine into coenzyme M (2-mercaptomethanesulfonic acid). Biochemistry 27, 74587462 .

[162] Consden, R., Gordon, A.H. and Martin, A.J.P. (1946) The identification of amino-acids derived from cysteine in chemically modified wool. Biochem. J. 40, 580582.

[163] Koshikawa, T., Nakashio, S., Kusuyama, K., Ichikawa, T. and Kondo, M. (1981) Presence of cysteic acid in the sporangium and its metabolic pathway during sporulation of $\mathrm{Ba}$ cillus subtilis NRRL B558. J. Gen. Microbiol. 124, 415423.

[164] Bonson, P.P.M., Spudich, J.A., Nelson, D.L. and Kornberg, A. (1969) Biochemical studies of bacterial sporulation and germination XII. A sulfonic acid as a major sulfur compound of Bacillus subtilis spores. J. Bacteriol. 98, 6268.

[165] Holst, P.B., Nielsen, S.E., Anthoni, U., Bisht, K.S., Christophersen, C., Gupta, S., Parmar, V.S., Nielsen, P.H., Sahoo, D.B. and Singh, A. (1994) Isethionate in certain red algae. J. Appl. Phycol. 6, 443446.

[166] Martelli, H.L. and Benson, A.A. (1964) Sulfocarbohydrate metabolism 1. Bacterial production and utilization of sulfoacetate. Biochim. Biophys. Acta 93, 169171.

[167] Godchaux III, W. and Leadbetter, E.R. (1984) Sulfonolipids of gliding bacteria: structure of the $N$-acylaminosulfonates. J. Biol. Chem. 259, 29822990.

[168] Anderson, R., Kates, M. and Volcani, B.E. (1978) Identification of the sulfolipids in the non-photosynthetic diatom Nitzschia alba. Biochim. Biophys. Acta 528, 89106.

[169] Bentley, R.K. and Holliman, F.G. (1970) Pigments of Pseudomonas species. Part III. The synthesis of dimethylaeruginosin B and aeruginosin B. J. Chem. Soc. (C) 1970, 2447 2457.

[170] Patai, S. and Rappoport, Z. (Eds.) (1991) The Chemistry of Sulphonic Acids, Esters and their Derivatives. Wiley, Chichester. 